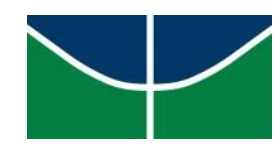

Universidade de Brasília

Instituto de Psicologia

Programa de Pós-graduação em Psicologia Social, do Trabalho e das Organizações

SUSTENTABILIDADE, RESPONSABILIDADE SOCIOAMBIENTAL E

COMPORTAMENTO ECOLÓGICO NO CONTEXTO

ORGANIZACIONAL

Patrícia Emanuele da Cruz Dias Ribeiro

Brasília 
Universidade de Brasília

Instituto de Psicologia

Programa de Pós-graduação em Psicologia Social, do Trabalho e das Organizações

SUSTENTABILIDADE, RESPONSABILIDADE SOCIOAMBIENTAL E

COMPORTAMENTO ECOLÓGICO NO CONTEXTO

ORGANIZACIONAL

Patrícia Emanuele da Cruz Dias Ribeiro

Tese de doutorado apresentada ao

Programa de Pós-graduação em Psicologia

Social, do Trabalho e das Organizações

como requisito parcial à obtenção do título

de Doutora em Psicologia Social, do

Trabalho e das Organizações.

Orientadora: Prof ${ }^{\mathrm{a}}$. Dr ${ }^{\mathrm{a}}$. Ana Lúcia Galinkin

Brasília 


\title{
SUSTENTABILIDADE, RESPONSABILIDADE SOCIOAMBIENTAL E COMPORTAMENTO ECOLÓGICO NO CONTEXTO ORGANIZACIONAL
}

\author{
TESE DE DOUTORADO AVALIADA E APROVADA PELOS SEGUINTES \\ EXAMINADORES:
}

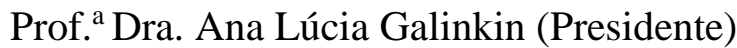 \\ Instituto de Psicologia - Universidade de Brasília
}

Prof. ${ }^{a}$ Dra. Maria das Graças Torres da Paz

Instituto de Psicologia - Universidade de Brasília

\author{
Prof. ${ }^{\text {a }}$ Dra. Elaine Rabelo Neiva \\ Instituto de Psicologia - Universidade de Brasília
}

Prof. a Dra. Cláudia Márcia Lyra Pato

Faculdade de Educação - Universidade de Brasília

Prof. a Dra. Camila Bolzan de Campos

Faculdade de Arquitetura - Universidade Federal do Rio Grande do Sul

Prof. Dr. Mário César Ferreira (Membro suplente)

Instituto de Psicologia - Universidade de Brasília 
Todo caminho da gente é resvaloso. Mas também, cair não prejudica demais a gente levanta, a gente sobe, a gente volta!

O correr da vida embrulha tudo. A vida é assim: esquenta e esfria, aperta e daí afrouxa, sossega e depois desinquieta. O que ela quer da gente é coragem.

(Guimarães Rosa) 


\section{Agradecimentos}

Realizar um doutorado não é uma tarefa fácil, e durante minha trajetória pude contar com o apoio essencial de algumas pessoas às quais gostaria de deixar publicamente registrado o meu agradecimento. Aos meus pais e à minha irmã, pela presença contínua em minha vida acadêmica, pelo interesse e apoio incondicional, comemorando comigo cada vitória e me incentivando a ser cada vez melhor, e principalmente pela base familiar que construímos a cada dia e que nos define muito além do que as palavras podem expressar. Ao meu marido, que com seu amor e carinho me apoiou em todos os momentos, dos mais angustiantes às mais felizes e radiantes comemorações que vivenciei nos últimos anos do doutorado, o que certamente foi essencial para eu chegar até aqui.

Agradeço à Universidade de Brasília, onde trabalhei e estudei nos últimos sete anos, e ao Programa de Pós-Graduação em Psicologia Social, do Trabalho e das Organizações (PPG-PSTO), por oferecer um curso de excelência reconhecida nacional e internacionalmente e por me formar mestre e doutora nessas áreas. À CAPES, que me permitiu desenvolver as atividades de estudo e pesquisa durante o doutorado com uma bolsa de estudos. À Instituição onde realizei a pesquisa contida nesta tese, bem como ao coordenador do Programa de Sustentabilidade, que prontamente recebeu a proposta e se dispôs a colaborar com o meu trabalho; aos participantes da pesquisa pela colaboração. Aos professores, não só do PPG-PSTO mas também de outros programas, com quem pude compartilhar conhecimentos e crescer profissionalmente. Agradeço especialmente aos avaliadores desta tese, pela disponibilidade, pelo interesse e pela avaliação criteriosa, competente e respeitosa do meu trabalho.

Agradeço com um carinho especial à minha orientadora, professora Ana Lúcia Galinkin, uma pessoa por quem tenho muita admiração pessoal e com quem tive o imenso prazer de trabalhar, que com profissionalismo e doçura me acolheu e com grande 
competência me orientou para o alcance de mais essa vitória. À professora Maria das Graças Torres da Paz, que me acompanha desde a graduação em Psicologia, por me orientar não só em aspectos acadêmicos mas também para a vida, e principalmente pela amizade sincera que construímos ao longo dos últimos onze anos. À professora Claudia Pato, pela disponibilidade e amizade com que sempre me recebeu e por construirmos um diálogo entre nossas áreas de atuação, cujo primeiro fruto é esta tese. Á professora Elaine Neiva, pelas orientações em análises de dados e pelo incentivo para que eu seguisse em frente em momentos de adversidade. À professora Camila Campos, da Universidade Federal do Rio Grande do Sul, pela disponibilidade e disposição em vir à Brasília participar da banca examinadora e também pelo interesse e incentivo à continuidade das minhas pesquisas.

Agradeço aos colegas dos grupos de pesquisa dos quais participei, especialmente ao Grupo de Pesquisa em Psicologia Social, Cultura e Diversidade e ao Grupo de Pesquisa em Educação Ambiental e Ecologia Humana, que me ofereceram ambientes de trabalho saudáveis e ampliaram significativamente os meus conhecimentos. Especialmente, aos colegas Luís Otávio e Rafael Moore pela parceria no desenvolvimento de algumas etapas da minha pesquisa. Às queridas amigas Raquel Barouh, Luana Britto, Juliana Guedes, Viviane Da Mata, Daniela Reis, Polyanna Andrade pelo apoio e pela parceria em pesquisas, congressos e na vida ao longo desses anos. Um agradecimento especial à Fabiana Damásio e à Julieta Ferreira, amigas sempre presentes que são como irmãs.

Finalmente, quero agradecer àquela que foi o meu maior estímulo, cuja companhia me deu forças para driblar as adversidades e concluir o doutorado: minha filha amada. Obrigada pela sua companhia, sua força, por me mostrar uma forma diferente de enxergar a vida e, principalmente, por me apresentar a real felicidade. 


\section{Sumário}

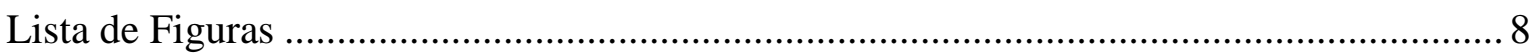

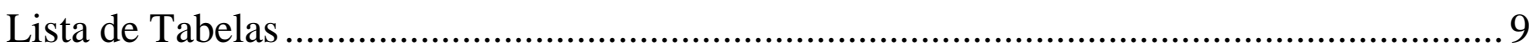

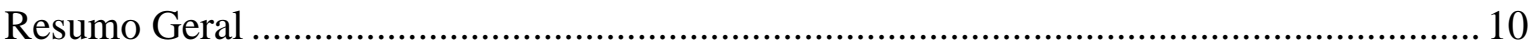

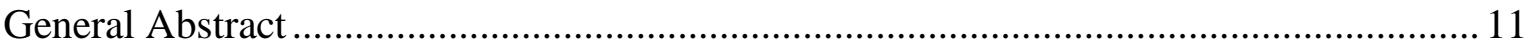

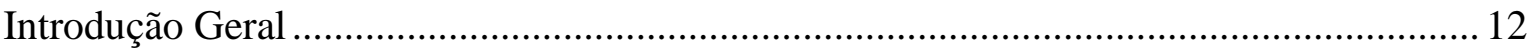

Manuscrito 01:

Representações sobre sustentabilidade em uma instituição pública brasileira.................... 30

Manuscrito 02:

Comportamento ecológico no ambiente organizacional: Evidências de validade de um

instrumento de medida e o efeito preditor de variáveis sociodemográficas .......................52

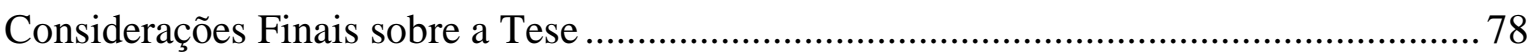

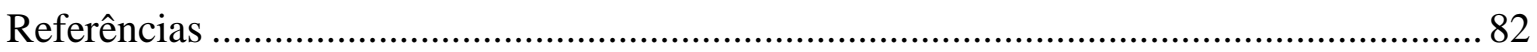

APÊNDICES:

Apêndice A. Termo de Consentimento Livre e Esclarecido - TCLE .................................... 89

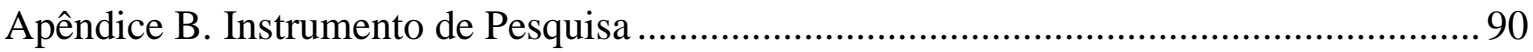




\section{Lista de Figuras}

Manuscrito 1. Representações sobre sustentabilidade em uma instituição pública brasileira

Figura 1. Dendograma de classes sobre as representações de sustentabilidade, com a classificação hierárquica descendente. .42

Figura 2. Dendograma da disposição espacial da relação entre as classes... .48 


\section{Lista de Tabelas}

Introdução Geral

Tabela 1. Organizações certificadas no Brasil e no DF

Manuscrito 1. Representações sobre sustentabilidade em uma instituição pública brasileira

Tabela 1. Caracterização da amostra geral e dos grupos de gestores e não gestores .37

Manuscrito 2. Comportamento ecológico no ambiente organizacional: Evidências de validade de um instrumento de medida e o efeito preditor de variáveis sociodemográficas

Tabela 1. Caracterização da amostra. .59

Tabela 2. Cargas fatoriais e comunalidades dos itens da Escala de Comportamento Ecológico em Ambiente Organizacional

Tabela 3. Resultados descritivos de comportamento ecológico no ambiente organizacional e desejabilidade social. .72

Tabela 4. Resumo do modelo de regressão padrão. .74

Tabela 5. Coeficientes do modelo de regressão .75 
Ribeiro, Patrícia Emanuele da Cruz Dias. Sustentabilidade, responsabilidade socioambiental e comportamento ecológico no contexto organizacional. Tese de Doutorado apresentada ao Instituto de Psicologia da Universidade de Brasília, Brasília, 2016, 92 páginas.

\section{Resumo Geral}

O cenário característico do modelo econômico vigente que se apresenta às organizações não envolve apenas a competitividade e a busca por lucros como demandas organizacionais. Pressões sociais, governamentais e de consumidores têm cada vez mais exigido uma postura de responsabilidade socioambiental (RSA) das organizações. Entretanto, ainda que políticas e práticas de sustentabilidade estejam sendo implementadas, elas dependem da atuação dos trabalhadores, pois muitas pressupõem mudanças na organização do trabalho, nos processos e até mesmo nas ações cotidianas desses colaboradores - atores centrais para colocar em prática as ações de RSA, que se refletem em comportamentos ecológicos no ambiente de trabalho. Esta tese apresenta dois manuscritos que incluem o relato de três estudos, um quantitativo e dois multimétodo, todos realizados em uma Instituição pública brasileira localizada em Brasília. O primeiro estudo (manuscrito 1), exploratório e descritivo, buscou identificar a compreensão dos trabalhadores sobre sustentabilidade. Os resultados da análise lexical dos dados, levantados por meio da realização de grupos focais, demonstraram certo distanciamento do discurso de gestores e não gestores sobre o tema, evidenciando a necessidade de ações direcionadas à educação ambiental nesse contexto. O segundo estudo (manuscrito 2) buscou evidências de validade da Escala de Comportamento Ecológico no Ambiente Organizacional por meio de análise fatorial exploratória. Os resultados psicométricos foram satisfatórios, evidenciando validade de construto e validade discriminante da medida para a amostra utilizada, ainda que necessite de aprimoramentos em sua composição de itens e mais estudos sobre sua adequação em diferentes tipos de ambientes organizacionais. O terceiro estudo (manuscrito 2) testou o efeito preditivo de variáveis sociodemográficas e profissionais sobre o comportamento ecológico no contexto laboral por meio de regressão logística. Os resultados foram positivos para sexo e tendenciosamente positivos para idade. Sugere-se a realização de mais estudos sobre sustentabilidade e outras variáveis relacionadas em diferentes contextos organizacionais.

Palavras-chave: Sustentabilidade; Responsabilidade socioambiental; Comportamento ecológico; Organizações. 
Ribeiro, Patrícia Emanuele da Cruz Dias. Sustainability, environmental social responsibility and ecological behavior within organizations. Doctor's Dissertation submitted to the Institute of Psychology, University of Brasília, Brasília, 2016, 92 pages.

\section{General Abstract}

The characteristic scenario of the current economic model that is presented to organizations not only involves competitiveness and the pursuit of profits as organizational demands. Social, governmental and consumers' pressures have increasingly demanded an environmental social responsibility (ESR) posture of companies. Therefore, the ethical enterprises have been implemented politics and practices of ESR, which depend on the workers' actions. It is because many of the organizational politics and practices require changes in work organization, organizational procedures and daily actions of these employees. They are the main actors to put into practice the ESR proposed actions. This dissertation presents two manuscripts that include the report of three studies, one is quantitative and the others are multi-method. They were developed at a Brazilian public institution located in Brasília. The first one (manuscript 1) was exploratory and descriptive, and aimed to identify the workers understanding of sustainability. Lexical analysis results showed some distance among managers and no managers' discourse, which reflects the need to driving actions to environmental education in this context. The second one (manuscript 2) sought validity evidence of the Ecological Behavior within Organizational Environment Scale through exploratory factor analysis, and presented suitable psychometric results considering construct and discriminatory validity. Meanwhile, the measure must be improved and applied in more studies to demonstrate its adequacy at different organizational contexts. The third study (manuscript 2) tested the demographic variables predictive effect over ecological behavior at workplace with logistic regression analysis. The results were positive to gender and tendentiously positive to age. Further studies about sustainability and related variables must be conducted at different organizational contexts.

Keywords: Sustainability; Environmental social responsibility; Ecological behavior; Organizations. 


\section{Introdução Geral}

O trabalho realizado pelos seres humanos resulta naturalmente em impacto no meio ambiente. No decorrer da história, esse impacto foi gradativamente aumentando e tendo consequências negativas de grandes proporções para a sociedade em geral. A intensificação do crescimento econômico mundial agravou os problemas ambientais, que, conforme Dias (2011), até 1962 eram abordados muito superficialmente. O autor apresenta ainda uma mudança nesse panorama a partir de 1968, com o surgimento de delineamentos mais estratégicos para o enfrentamento dos problemas ambientais. Do final da década de 1960 a meados da década de 1990 houve uma intensificação nas discussões internacionais sobre esse tema, o qual passou a ser pauta obrigatória nos encontros mundiais.

Entretanto, é importante ressaltar que, em meio a tantos debates e esforços em âmbito mundial, os problemas socioambientais aumentavam. Paralelo a isso, o aumento de denúncias sobre problemas de contaminação do meio ambiente contribuiu significativamente para a criação de normas e regulamentos, bem como órgãos reguladores e organizações não governamentais (ONGs) atuantes em tais questões (Dias, 2011). Atualmente, são adotados alguns critérios internacionais de regulação, tais como as normas desenvolvidas pela International Organization for Standardization (ISO). As normas ISO 14000 determinam diretrizes para a gestão ambiental nas organizações, praticada por meio de um Sistema de Gestão Ambiental (SGA), conforme estabelecido pela ISO. Para normatizar questões relacionadas à vertente social, as normas ISO 26000 orientam as organizações para atuarem de forma socialmente responsável.

Além das certificações da ISO, outras foram criadas com ênfases específicas em elementos importantes de preocupação socioambiental, tais como: Leadership in Energy and Environmental Design (LEED), uma certificação mais pragmática com parâmetros pré-estabelecidos; $A Q U A$, uma certificação mais subjetiva, pois ainda não possui 
parâmetros de comparação e estabelecimento de metas; e Dow Jones Sustainability Index (DJSI), uma série de índices de avaliação do desempenho de sustentabilidade empresarial, que tem como base o tripé social, ambiental e econômico. Um levantamento realizado por Ribeiro e Ferreira em 2013, a partir de dados obtidos em relatórios disponibilizados na internet, indicou a quantidade de organizações brasileiras certificas pelo LEED, AQUA, ISO 14001 e DJSI, e, destas, quantas se localizam na região do Distrito Federal (Tabela 1).

Tabela 1.

Organizações certificadas no Brasil e no DF

\begin{tabular}{l|c|c}
\hline \multicolumn{1}{c|}{ Certificação } & Organizações Brasileiras & Organizações do DF \\
\hline LEED & 408 & 8 \\
\hline ISO14001 & 222 & 1 \\
\hline DJSI & 92 & - \\
\hline AQUA & 65 & 3 \\
\hline \hline
\end{tabular}

É possível observar o número reduzido de organizações brasileiras que possuem as certificações em questão, considerando-se o mercado internacional, e um número consideravelmente reduzido de organizações do DF que se incluem nesse grupo. Destacase que o levantamento de Ribeiro e Ferreira (2013) não identificou organizações no DF com certificação DJSI, e não incluiu na pesquisa a certificação ISO 26000.

A tendência atual é de que cada vez mais organizações busquem certificações, uma vez que ser certificado em algum aspecto de sustentabilidade também significa possuir maior destaque e prestígio no mercado. Inclusive para a inserção das organizações no mercado internacional há exigências que incluem determinados tipos de certificações. Observa-se, portanto, que ainda há necessidade de uma discussão mais aprofundada sobre as certificações de sustentabilidade, a fim de se conseguir meios de controle que busquem 
a garantia de que políticas e práticas organizacionais sejam implementadas objetivando efetivamente a sustentabilidade global, e não apenas para fins de marketing empresarial.

Além do contexto privado, o Brasil tem buscado alcançar metas de sustentabilidade envolvendo organizações públicas. Para tanto, lançou no final da década de 1990 a Agenda Ambiental na Administração Pública (A3P), de forma a incentivar o protagonismo e a reflexão crítica de gestores e servidores públicos sobre as questões socioambientais. Coordenada pelo Ministério do Meio Ambiente (MMA), essa iniciativa envolve a redução de consumo e o uso responsável de recursos naturais e materiais no local de trabalho, a partir de uma mudança de atitudes e hábitos nesse contexto (MMA, 2009).

Tais iniciativas, tanto no contexto de organizações privadas quanto públicas, demonstra a busca pelo alcance de metas de sustentabilidade, cada qual com suas motivações inerentes à natureza delas, bem como com os mecanismos de atuação que distintamente possuem. É perfeitamente possível observar que tais metas ainda não foram alcançadas, e pode-se dizer que ainda há muito o que se modificar em termos culturais, mas tal preocupação reflete a apropriação de uma responsabilidade socioambiental que tem sido compartilhada pelas mais diferentes esferas - e as organizações, além de possuírem um alcance maior, têm sido cobradas pela sua implicação nesse problema mundial.

Considerando-se que a existência de uma organização em um meio provoca impactos positivos e negativos no ambiente - em maior ou menor grau a depender do seu porte e do alcance de sua atuação -, entende-se que a relação entre as organizações e o cenário onde estão inseridas deve ser, em certa medida, equilibrada e ética - pois a falta de ética impacta cedo ou tarde na própria organização. Esta, de forma geral, tem assumido um papel cada vez mais central nas questões relacionadas à sustentabilidade e, como seu impacto negativo não pode ser desconsiderado, sua responsabilização por minimizá-lo tem sido uma exigência mundial e de mercado. Atualmente, stakeholders, além das próprias 
diretrizes organizacionais, demandam políticas e ações de responsabilidade socioambiental (RSA) e atuam para tentar equilibrar seus efeitos no meio.

A RSA, conforme Cabestré, Graziadei e Filho (2008), diz respeito ao posicionamento adotado pelas organizações em relação ao ambiente em que se inserem, de forma a avaliar o impacto da sua presença na comunidade com a qual estabelece relações. De acordo com os autores, as organizações devem incorporar ações que objetivem promover a qualidade de vida da sociedade, considerando um ponto de vista ético. No entanto, Aligleri, Aligleri e Kruglianskas (2009) defendem que a implicação das organizações na era de responsabilidade vivenciada mundialmente nas últimas décadas não se trata apenas de uma questão ética, mas principalmente econômica e mercadológica.

O cenário característico do modelo econômico vigente que se apresenta às organizações não envolve apenas a competitividade e a busca por lucros como demandas organizacionais. Além disso, pressões sociais, governamentais e de consumidores exigem um posicionamento de RSA das organizações. Assim, além das questões éticas que já envolviam $\mathrm{o}$ funcionamento $\mathrm{e}$ as relações inter $\mathrm{e}$ intraorganizacionais, a ética socioambiental passou a ser destaque nessa época em que tantos encontros mundiais discutem sobre a sustentabilidade do planeta.

Assim, em oposição ao capitalismo convencional, novas formas de produção começam a emergir no mercado, considerando-se não apenas o lucro mas também uma contribuição para a preservação ambiental - o chamado capitalismo natural (Pinheiro, 2003). Entretanto, a implementação de novas práticas requer mudanças, e alguns pesquisadores salientam que a cultura organizacional está relacionada a esse processo, direta ou indiretamente (Neiva \& Paz, 2007). De acordo com Linnenluecke e Griffiths (2010), pesquisas sugerem que o sucesso da mudança na cultura organizacional depende de valores e fundamentos, que afetam a forma como a sustentabilidade corporativa é 
implementada e os tipos de resultados observáveis. Isto porque não há um único tipo de cultura orientada para a sustentabilidade, e os fundamentos ideológicos da cultura organizacional influenciam tanto no processo quanto nos resultados.

Considerando-se ainda o nível individual (micro-organizacional), os trabalhadores advêm de diferentes culturas e enfatizam aspectos distintos na sua busca pela sustentabilidade, variando o foco em desenvolvimento de pessoal, eficiência de recursos, proteção ambiental ou engajamento dos stakeholders (Linnenluecke \& Griffiths, 2010). Portanto, o sucesso da implementação de políticas orientadas para a sustentabilidade depende não apenas de características macro organizacionais, mas principalmente do engajamento dos trabalhadores nas ações de RSA propostas.

Nesse sentido, torna-se necessário não apenas o endosso dos trabalhadores a tais diretrizes, mas principalmente seu protagonismo nas ações implementadas. Posto isto, a RSA deve ser traduzida em práticas ecológicas que também envolvam os trabalhadores e ainda considerem suas necessidades - o que pode resultar, por exemplo, no desenvolvimento de vínculos do indivíduo com a organização e o trabalho, avaliação favorável das políticas de gestão da empresa, bem-estar dos trabalhadores e, ainda, um melhor desempenho deles no trabalho.

Por se tratar de um fenômeno complexo, abordado de diferentes formas, para a mensuração da RSA nas organizações é necessário que haja um instrumento que alcance as ações sociais e ambientais adotadas por elas. Tal medida deve também estar alinhada ao pressuposto econômico inerente ao funcionamento organizacional, de forma com que consiga integrar os três focos subjacentes à sustentabilidade: pessoas, planeta e lucro. Rahman e Post (2012) salientam a necessidade de haver transparência, validade e confiabilidade nessa medida, sendo necessário que os dados referentes a essas características sejam explicitados na literatura. 
Nessa direção, Ribeiro, Ferreira, Almeida, Puente-Palacios \& Barbosa (2014) realizaram um estudo para identificar os esquemas mentais que gestores socioambientais possuem sobre RSA. A partir das entrevistas realizadas, os achados demonstraram oito categorias temáticas vinculadas à compreensão que eles têm do fenômeno, sendo elas: responsabilidade ambiental, responsabilidade social, políticas socioambientais, práticas socioambientais, estratégias de gestão, certificação, comunicação interna e foco no cliente.

Além disso, as autoras encontraram evidências de que, ainda que o objetivo das organizações estudadas seja a promoção de sua imagem no mercado (marketing), o desenvolvimento de políticas e práticas de RSA favorecem a minimização ou compensação de seus efeitos socioambientais negativos. Isto vai ao encontro do que Pato e Campos (2011) propõem sobre a importância maior recair sobre os efeitos positivos das ações em si, e não a intencionalidade consciente das práticas de sustentabilidade.

O estudo apresentado forneceu as bases necessárias para a elaboração de uma escala de medida de RSA nas organizações, elaborado por Ribeiro, Puente-Palacios e Ferreira (2015). O objetivo desse instrumento é identificar a percepção dos trabalhadores sobre a realização de ações de RSA nas organizações em que trabalham e o quanto eles consideram importante tais ações serem praticadas pelas organizações em geral (endosso). A medida apresentou evidências de validade de construto, com bons índices psicométricos e adequação para mensurar o fenômeno. Além disso, esse instrumento também permite identificar o nível de ajuste entre práticas organizacionais e o endosso dos trabalhadores, o que fornece dados sobre congruência entre comportamentos organizacionais e individuais.

Sobre esse novo posicionamento das organizações em prol da sustentabilidade do planeta observa-se na literatura certa diversidade conceitual, com diferentes nomenclaturas que tratam sobre o tema: responsabilidade social empresarial, responsabilidade socioambiental, responsabilidade social corporativa, responsabilidade ambiental, entre 
outras. Seja qual for a denominação, inclui-se o termo ambiental, social ou ambos, e percebe-se que a responsabilidade se faz presente em muitas dessas nominações.

No esforço de se compreender o significado e a pertinência de um termo em um contexto específico, a análise conceitual apresenta-se como uma ferramenta útil e adequada

para esclarecer tais elementos. É relevante, portanto, que se faça uma análise mais cuidadosa do uso desse termo tanto para uma melhor compreensão de seu significado, quanto para justificar sua adoção neste trabalho A seguir, será apresentada uma breve análise do uso do termo responsabilidade, com base em referenciais teóricos da área da filosofia da linguagem, tais como Wittgenstein (1953/1987) e Ryle (1949).

Análise conceitual do termo responsabilidade

Para alguns teóricos é imprescindível distinguir entre desempenho ambiental e social corporativo, uma vez que há objetivos e metas específicos a se alcançar nessas frentes, e as iniciativas requeridas para tanto são também distintas (Ones \& Dilchert, 2012). No entanto, a realidade prática das organizações demonstra que o foco principal não é exatamente esse, pois embora algumas de suas ações sejam aplicadas com maior ênfase em elementos sociais ou ambientais, no discurso organizacional é possível observar que um aspecto complementa o outro (Ribeiro et al, 2014). Além disso, o termo socioambiental é compreendido considerando-se a interdependência dos elementos envolvidos, em uma perspectiva dinâmica e sistêmica, não havendo como abordar um sem considerar o outro.

Falar em responsabilidade socioambiental reflete ainda uma visão distinta daquela que fragmenta a realidade em setores e prioriza um elemento em detrimento de outros, fazendo com que o foco não seja dado ao termo social ou ambiental, mas no que se pretende fazer com eles, que é ser responsável pelos fatores socioambientais. Com estas considerações, surgem alguns questionamentos: o que se entende por responsabilidade no uso típico da linguagem e como esse termo é usado no contexto organizacional? 
Encontra-se no dicionário Houaiss (Houaiss \& Villar, 2009) a definição de responsabilidade como um substantivo do sexo feminino, que significa "dever ou capacidade de responder pelos atos próprios ou de outros" (p.651). Seu antônimo é irresponsabilidade. Uma segunda definição apresentada é "qualidade de se poder atribuir a alguém ou a algo, a causa de um fato, situação etc.” (p. 651). Em se tratando da responsabilidade atribuída a algum indivíduo ou entidade, entende-se que este(a) possua a característica de ser responsável, ou seja, “1 que(m) responde pelos seus atos ou pelos de outra pessoa; 2 que(m) assume ou cumpre seus deveres; 3 que(m) deve prestar contas perante certas autoridades; 4 que(m) foi a causa ou a origem de algo" (p. 651).

Esse conjunto de significados atribuídos ao termo sob análise revela que a compreensão do que seja responsabilidade está permeada por aspectos éticos de conduta, o que requer um esclarecimento, sob um ponto de vista mais filosófico, sobre a ética da responsabilidade - uma das escolas de pensamento ético, que propõe o princípio da responsabilidade. Em decorrência da concepção antropocêntrica do indivíduo como um produto da cultura, o princípio da responsabilidade sistematiza normas sociais e políticas a partir de ações advindas de um todo coletivo (Borja, 2010). Ser responsável, portanto, seria uma ação resultante de interações sociais estabelecidas em prol de um determinado objetivo, dependente do coletivo social. Ou seja, envolve um julgamento feito por parte de alguém sobre o ato ou comportamento qualificado como responsável ou não.

Wittgenstein (1953/1987), no entanto, propõe a busca pelo uso que se faz das palavras, ao invés do seu significado, o qual, segundo o autor, é definido pelo uso, e não o contrário. Para tanto, a análise conceitual se apresenta como uma ferramenta útil para se identificar a lógica dos usos dos conceitos, descrevendo seus usos e funções para tornar possível o estabelecimento das fronteiras do conceito - a chamada geografia lógica dos conceitos (Harzem \& Miles, 1978). 
O primeiro critério a se observar é o princípio polar, ou seja, as delimitações do conceito - o que ele exclui e a que se opõe. Analisando-se inicialmente a família conceitual do termo responsabilidade, percebe-se que seu uso típico aproxima-se a comprometimento, consciência, cuidado. Ser responsável em relação a algo está diretamente relacionado a ser comprometido com esse objeto, ou ter consciência dele, ter cuidados com ele. Por exemplo, ao se falar de responsabilidade socioambiental está intrínseca a noção de comprometimento com as pessoas e com o meio ambiente, a consciência sobre problemas socioambientais e os cuidados necessários às duas esferas, social e ambiental.

O princípio polar coloca responsabilidade, bem como consciência, comprometimento, cuidado e atenção, em oposição a irresponsabilidade, falta de consciência, descomprometimento, negligência, descuido e falta de atenção. Em um sentido mais profundo, neste polo de oposição pode-se incluir criminoso e mal intencionado, considerando-se o contexto de uso do termo em análise. Assim, dizer que determinada organização é socioambientalmente responsável significa afirmar que ela é responsável, cuidadosa, atenciosa, consciente e comprometida com as questões sociais e ambientais relacionadas à sua atuação ou sua simples existência em um espaço (comunidade, cidade ou região). Uma organização que não apresenta tais características é classificada de forma oposta, como irresponsável, negligente, descuidada, sem consciência ou comprometimento com o impacto socioambiental causado por ela.

Sabe-se, no entanto, que o alcance das ações de responsabilidade socioambiental das organizações possui limitações. É fato que a simples existência de um ser ou entidade no planeta causa impacto, em maior ou menor proporção, seja no meio ambiente natural, na sociedade ou comunidade na qual se insere. Retomando-se então a função do conceito de responsabilidade no contexto apresentado, em uma época em que a preocupação com a sustentabilidade ambiental se coloca como pauta de grandes discussões internacionais, 
entende-se que, apesar das limitações, as organizações possuem um papel significativo nessa problemática. Se por um lado elas devem assumir essa responsabilidade, por outro é fato que elas não deixarão de gerar impactos socioambientais. Nesse sentido, suas iniciativas devem ser realistas e estar de acordo com o seu alcance em contribuir positivamente para tais questões.

Analisando-se o uso do termo no cenário organizacional, indaga-se então: o que uma empresa deve fazer para ser socioambientalmente responsável? Inicialmente, deve possuir valores congruentes com essa proposta - alguns princípios norteadores da conduta organizacional, desde os processos internos até o contato com os diferentes stakeholders. Trata-se, ainda, da preocupação com a forma de trabalho, com processos e produtos, envolvendo escolhas responsáveis em prol da sustentabilidade. Ou seja, a organização deve estar atenta aos aspectos socioambientais, para atuar causando o menor impacto negativo possível e, quando necessário, oferecer uma contrapartida pelos danos causados por ela.

Nesse sentido, são envolvidos verbos e condições disposicionais associados a essa ideia de responsabilidade socioambiental. Responsabilidade envolve ser responsável, e responsável é a forma de agir. Trata-se, portanto, de um conceito disposicional, e não de ação propriamente dita. De acordo com Ryle (1949), conceitos disposicionais não são ocorrências, e sua função é resumir ou relacionar ocorrências passadas observadas ou conhecidas, e ainda predizer ocorrências futuras, episódicas.

Nessa linha teórica, responsabilidade poderia ser categorizada como um conceito disposicional aberto, uma vez que, conforme Ryle (1949), esse tipo de conceito aceita diversas ocorrências que podem preencher a cláusula se-então relacionada ao termo. Significa dizer que se a organização se preocupa com o meio ambiente, então ela é ambientalmente responsável. Ou ainda, se a organização está atenta à comunidade na qual 
ela está inserida, então ela possui consciência social; se a organização busca minimizar/prevenir/compensar o seu impacto socioambiental, então ela é responsável.

Além disso, dizer que uma organização é socioambientalmente responsável pressupõe tendência, disposição ou propensão a realizar determinadas ações e não outras. Espera-se, por exemplo, que ela desenvolva parcerias com outras organizações que também atuem de forma responsável com o meio ambiente e a sociedade. Também se espera que busque economizar recursos em seus processos organizacionais, evitando o desperdício ou uso indevido, inconsciente e irresponsável de tais recursos.

Algumas ações típicas teriam relação com a regulamentação das atividades organizacionais, o atendimento a certos padrões com base em normas ou manuais de procedimentos. Para tanto, algumas certificações promovem uma forma de avaliar as organizações de um modo mais formal com relação à responsabilidade socioambiental. Algumas dessas certificações são a ISO 14001, relacionada ao sistema de gestão ambiental nas organizações, e a ISO 26000, relacionada à responsabilidade social delas. Há também selos, prêmios e outras formas de reconhecimento formal sobre tais quesitos empresariais.

Há, no entanto, uma particularidade do conceito que merece destaque e uma análise específica. Responsabilidade é uma expressão aplicada a contextos nos quais ações que não deveriam ocorrer de fato ocorrem, ficando implícito o que deve ser feito ou não. Mas não caberia falar em responsabilidade ambiental referente a uma ação que não causa dano ambiental. Em outras palavras, a lógica da certificação social/ambiental é inversa ao uso do termo responsável no cotidiano. Na linguagem cotidiana há a preocupação em listar ações que, se não forem empreendidas, demonstram a irresponsabilidade da organização. A ideia de responsabilidade de um agente cabe para atos não meritosos, que não deveriam ter ocorrido. 
A lógica da certificação é contrária, uma vez que são listadas ações que devem ser realizadas para a organização ser considerada responsável. São listadas ações que devem ser realizadas pelo agente, neste caso a organização, e as ocorrências que indicam que uma empresa é socioambientalmente responsável tipicamente podem ser de prevenção, compensação ou predição de impactos socioambientais. O uso desse conceito de responsabilidade se aplica quando a organização atende ao que se espera de uma atuação consciente, atenciosa, cuidadosa, preocupada com aspectos socioambientais envolvidos nas suas atividades de funcionamento.

Em suma, a responsabilidade socioambiental parece ser um termo que revela atuação intencional e voluntária, uma vez que para efetivamente se comportar de forma responsável a organização deve não apenas ter o discurso, mas apresentar evidências de sua atuação na busca em alcançar esse objetivo de causar o menor dano possível ao meio. Observa-se, portanto, a necessidade de haver coerência entre o que a organização diz que faz, o que ela realmente faz e o que as pessoas percebem que ela faz, para que se possa afirmar que ela é ou não responsável.

Considerando-se a existência de diferentes nomenclaturas na literatura da área referentes à RSA no contexto organizacional, a análise realizada representa um esforço analítico-conceitual para esclarecer o que vem a ser a responsabilidade, em um sentido geral, podendo ser aplicada à RSA das organizações. Neste caso, a aplicação pode ser voltada para as próprias questões socioambientais, mas o termo também pode ser aplicado a outras questões também. Destaca-se que as reflexões que foram apresentadas não esgotam o assunto, tampouco a análise conceitual desse termo. 
Considerações teóricas e proposição de uma definição de responsabilidade socioambiental das organizações

Considerando-se a diversidade de nomenclaturas e conceitos encontrados na literatura para se referir à RSA, faz-se necessário uma definição do que vem a ser a responsabilidade socioambiental das organizações. Partindo-se, então, da análise realizada sobre o termo responsabilidade, entende-se que se trata de um conceito disposicional aberto e polarizado. Ou seja, ele não é a ação propriamente dita, o comportamento em si, mas reflete a intenção de comportamento, tratando-se ainda da qualidade da ação resultante. Além disso, possui polaridades distintas: responsabilidade versus irresponsabilidade. Portanto, não cabe avaliar o termo em um continuum, pois ou se é responsável, ou não - e nesse caso a qualidade atribuída é a de ser irresponsável.

Além disso, a análise conceitual revelou que, em se tratando de uma intenção de comportamento, além da ação resultante, possui antecedentes. Destes, vale ressaltar as atitudes e os valores, em se tratando de comportamentos ambientais. Considerando-se aspectos ecológicos, Stern e Dietz (1994) propuseram uma teoria baseada em valores para a preocupação ambiental, a qual pressupõe que as atitudes ambientais são o resultado de um conjunto geral de valores pessoais do indivíduo. Tal teoria diferencia três tipos de atitudes ambientais: egoístas, baseadas em crenças sobre o efeito da destruição ambiental sobre o indivíduo em si; sócio-altruístas, baseadas em benefícios/objetivos humanos de preservação ambiental para prevenção de consequências sobre outras pessoas; e biocêntricas, baseadas no valor inerente ao meio-ambiente, considerando o ser-humano como parte dele.

Valores pessoais são definidos como critérios ou metas que transcendem situações específicas, que são ordenados por sua importância e que servem como princípios que guiam a vida do indivíduo (Schwartz, 1999). Nesse sentido, eles podem estar relacionados ao comportamento ecológico, seja qual for o contexto. Embora as pesquisas na área 
indiquem uma fraca relação entre valores e comportamento, é fato que os valores guiam a conduta dos indivíduos, como bem define Schwartz (1999). Assim, entende-se que mais pesquisas devem ser realizadas, considerando-se principalmente outras formas de mensuração do construto, uma vez que a desejabilidade social é um fator preponderante que pode afetar o resultado das pesquisas.

Além dos valores pessoais, valores organizacionais também podem influenciar no tipo de estratégias de RSA adotadas pelas organizações. Conforme Tamayo (1996), os valores organizacionais são "princípios ou crenças, organizados hierarquicamente, relativos a estados de existência ou a modelos de comportamento desejáveis que orientam a vida da empresa e estão a serviço de interesses individuais, coletivos ou mistos" (p. 182).

Entende-se que para a organização obter melhores resultados com práticas de RSA é necessário o ajuste daquilo que a ela considera importante e que se traduz em práticas implementadas e o que é valorizado pelos trabalhadores sobre aspectos socioambientais. Assim, é pertinente esperar tais resultados à medida que tanto a organização quanto o seu corpo de trabalhadores outorguem importância, ou valorizem, a preservação do meio ambiente e das comunidades afetadas pelas ações organizacionais. Além disso, espera-se que as organizações sejam coerentes na sua preocupação com aspectos ambientais, sociais e econômicos referentes tanto ao ambiente externo, quanto ao contexto laboral.

Nesse sentido, Schultz e Zelezny (1999) realizaram um estudo multinacional sobre a relação entre valores e atitudes, e seus achados revelaram que valores de universalismo estão positivamente relacionados ao NEP e ao ecocentrismo, enquanto valores de poder e tradição estão negativamente relacionados a esses fatores. Por outro lado, benevolência está negativamente relacionada ao antropocentrismo e valores de poder, tradição e segurança se relacionam positivamente com essa visão de mundo. 
Considerando-se as teorizações sobre o fenômeno, bem como a análise conceitual aqui apresentada, pode-se dizer que existe um fluxo de elementos até a ação propriamente dita. Valores predizem crenças, que por sua vez antecedem atitudes, que predizem a intenção de comportamento que enfim leva ao comportamento em si. Aplicado às questões ambientais, com base em alguns modelos encontrados na literatura (Dunlap, Van Liere, Mertig \& Jones, 2000; Stern, 2000; Stern, Dietz, Abel, Guagnano \& Kalof, 1999), pode-se dizer que valores hedônicos e egoísticos tendem a anteceder crenças antropocêntricas, que por sua vez tendem a anteceder atitudes negativas frente ao meio ambiente, o que provavelmente levaria a uma tendência de intenção de comportamento de irresponsabilidade, culminando em um comportamento não ecológico.

Por outro lado, valores altruístas e biosféricos tendem a anteceder crenças ambientais ecocêntricas, que tenderiam a anteceder atitudes ambientais positivas, as quais levariam a uma intenção de comportamento de responsabilidade ambiental e comportamentos ecológicos. Não se trata, no entanto, de um fluxo direto, devendo-se considerar nesse modelo certa flexibilidade nas relações propostas. Essas são uma possibilidade de relações entre os construtos apresentados, mas seria possível também a ocorrência de algumas variações, uma vez que o próprio campo de estudos do comportamento aponta influências de variáveis diversas entre valores e comportamentos.

Considerando-se o exposto, a RSA antecede a ação em si, podendo norteá-la de acordo com os objetivos que se deseja alcançar - neste caso, em prol da sustentabilidade. Sobre a gestão ambiental nas organizações, Pol (2003) defende que se trata de uma gestão do comportamento humano, considerando tanto o ambiente externo quanto o interno das organizações. Considerando ainda as organizações de natureza pública, o autor afirma que as práticas adotadas por elas devem incorporar os valores do desenvolvimento sustentável na organização social e nas metas corporativas da organização e da Administração Pública, 
buscando-se a melhoria contínua da gestão. No entanto, parecem haver alguns desafios, refletidos em dois eixos dimensionais distintos: na intervenção e na gestão propriamente dita - ambos baseados nos parâmetros da sustentabilidade como novo valor social positivo (Pol, 2003).

Quanto ao envolvimento dos trabalhadores em ações planejadas para atingir um determinado fim, estudiosos do comportamento humano asseveram que um dos principais preditores é a percepção do indivíduo quanto à relevância dessa meta, além da percepção de sua capacidade de executar as ações (Bandura, 1994). Trazendo essa lógica interpretativa para o tema aqui discutido, é pertinente defender que as ações implementadas pela organização terão maior probabilidade de serem endossadas pelos funcionários na medida em que eles as considerarem relevantes. Isto é, as pessoas tendem a colaborar e efetivamente aderir às práticas socioambientais desenvolvidas pela organização quando as percebem como realmente importantes para a finalidade a que se propõem.

Outro aspecto relevante são as características específicas do ambiente de trabalho, que têm uma importante implicação para a adoção de comportamentos ambientais nesse contexto e acabam por determinar a significância de diversos fatores psicológicos para explicar tais comportamentos (Ruepert, Steg \& Keizer, 2015). A busca por tal explicação conta com uma diversidade de teorias sobre elementos que predizem o comportamento pro ambiental, tais como: teoria de valores, goal-framming theory, teorias que supõem que o comportamento é o resultado de análises de custo-benefício e teoria de hábitos.

Além das considerações teóricas e da análise conceitual aqui apresentadas, faz-se necessário conhecer algumas definições de RSA encontradas na literatura. Alguns autores definem a responsabilidade organizacional frente às questões socioambientais como sendo a integração de preocupações ambientais, sociais e econômicas na cultura, na tomada de decisões, na estratégia e nos processos organizacionais - sendo que para serem 
consideradas responsáveis as organizações devem promover o bem-estar social e humano reduzindo o seu impacto ecológico e assegurando o alcance efetivo dos objetivos organizacionais, simultaneamente (Linnenluecke \& Griffiths, 2010).

Outros teóricos caracterizam a RSA pela adoção de atitudes e ações em prol da sustentabilidade que, com base em valores éticos e morais, objetivam minimizar os impactos negativos causados pelas organizações ao ambiente em que se encontram (Cabestré, Graziadei \& Filho, 2008). Há também quem relacione a RSA ao compromisso da organização em adotar e transmitir valores, condutas e procedimentos, no sentido de alcançar um contínuo aperfeiçoamento de seus processos, mas também em prol de uma melhor qualidade de vida da sociedade do ponto de vista ético, social e ambiental (Tachizawa, 2011).

Tendo em vista a diversidade conceitual encontrada na literatura, com certa carência de compreensões claras sobre o fenômeno em questão, faz-se necessário a elaboração de uma definição pertinente para a Responsabilidade Socioambiental das Organizações (RSA-O). Partindo-se das concepções teóricas encontradas, bem como das considerações e análises aqui apresentadas, a RSA-O é o comprometimento das organizações com a sustentabilidade, pressupondo o reconhecimento das consequências socioambientais provenientes de processos e/ou produtos relacionados às suas atividades, baseado em valores auto transcendentes e uma visão de mundo ecocêntrica. Caracteriza-se pela adoção de uma cultura orientada para a sustentabilidade que integra a consciência socioambiental e o foco geral da organização em suas estratégias de gestão. A RSA-O se manifesta em ações ecológicas no nível micro e macro organizacional, de forma a refletir a o comprometimento socioambiental da organização em tomadas de decisão, na adoção de políticas e na condução dos processos necessários para o alcance de suas metas. 
Considerando-se o exposto nesta introdução geral, esta tese aborda a responsabilidade socioambiental das organizações, no sentido de implementação de práticas que visem a gestão, a preservação e o consumo consciente de recursos naturais. Mas além das iniciativas organizacionais é preciso que o comportamento das pessoas envolvidas seja congruente com o objetivo a ser alcançado. Portanto, também serão abordados os comportamentos dos trabalhadores, neste caso caracterizados como comportamentos ecológicos - definidos como ações humanas que visam contribuir para a proteção do meio ambiente ou para a minimização do impacto ambiental naturalmente provocado por outras atividades (Pato \& Campos, 2011). A sustentabilidade, portanto, é abordada aqui como o arcabouço que embasa a adoção de políticas e práticas organizacionais de RSA, sendo definida como o equilíbrio entre o que é bom para as pessoas e suas comunidades e o necessário para a conservação dos recursos naturais e sociais, tendo como finalidade garantir a sobrevivência dos seres humanos do presente e do futuro (Corral-Verdugo, 2010).

Esta tese está estruturada em formato de manuscritos, sendo composta por quatro partes: 1) Introdução geral ao tema da tese, que apresenta o eixo temático central e relaciona os manuscritos que integram a tese; 2) Manuscrito 1, que aborda o compromisso das organizações com a sustentabilidade, apresentando um estudo sobre as representações de sustentabilidade na unidade de uma instituição pública brasileira localizada em Brasília; 3) Manuscrito 2, que versa sobre os comportamentos ecológicos de trabalhadores dessa mesma instituição pública e apresenta dois estudos: um sobre evidências de validade de uma medida de CE no ambiente organizacional, e outro correlacional, que testa um modelo preditivo de características sociodemográficas sobre o CE no ambiente de trabalho; e 4) Considerações finais sobre a tese, que apresenta ainda as limitações e a proposição de uma agenda de pesquisa. 


\title{
MANUSCRITO 01
}

\section{Representações sobre sustentabilidade em uma instituição pública brasileira}

\begin{abstract}
Resumo
A sustentabilidade tem sido foco de debates internacionais e o envolvimento de organizações na busca pelo equilíbrio socioambiental tem crescido em decorrência de demandas de mercado e pressões sociais. Nesse cenário, para uma atuação organizacional efetiva, é relevante conhecer o que trabalhadores entendem sobre esse fenômeno. Esta pesquisa teve como objetivo identificar as representações de trabalhadores de uma Instituição pública brasileira sobre sustentabilidade, por meio de um estudo exploratório e descritivo com grupos de gestores e não gestores. Um único corpus textual foi submetido à análise lexical, que reteve 264 segmentos de texto $(95,83 \%$ do total) e dividiu o corpus em quatro classes: Energia Elétrica (20,2\%), Conceito Ampliado (25,3\%), Água e Copos $(32,4 \%)$ e Lixo e Papel $(22,1 \%)$. Os resultados presentes nas classes representam elementos relacionados a temas trabalhados pelo Programa de Sustentabilidade da Instituição, evidenciando certo distanciamento nas representações de gestores e não gestores.
\end{abstract}

Palavras-chave: Sustentabilidade; Organização pública; Representações

\section{Representations of sustainability within a Brazilian Public Institution}

\begin{abstract}
Sustainability have been focused in international debates and the organization's involvement in the search for environmental social balance have been growing due to market demands as well as social pressures. In this scenario, an organizational effective performance it is relevant to understand the workers knowledge about this phenomenon. The present research aimed to identify the workers representations of sustainability at a Brazilian Public Institution by an exploratory and descriptive study with managers and no managers groups. A unique textual corpus was submitted to a lexical analysis. It retained 264 textual segments $(95,83 \%$ of total) and divided the corpus into four classes: Electric energy (20,2\%), Expanded concept (25,3\%), Water and disposable cups $(32,4 \%)$ and Garbage and Paper (22,1\%). The classes' results represent elements related with themes
\end{abstract}


that have been worked by the Institution's Sustainability Program. They also give evidence of some distance among managers and no managers' representations of sustainability.

Keywords: Sustainability; Public organization; Representations

\section{Introdução Teórica}

Atualmente, o planeta encontra-se em estado de alerta geral para as questões socioambientais, e esforços conjuntos vem sendo empreendidos no sentido de se estabelecer e se alcançar metas de sustentabilidade. Frente a tantas crises registradas em diferentes localidades do globo, a preocupação com questões sociais, ambientais, culturais, políticas, econômicas e psicológicas tem sido compartilhada pelas mais diversas nações. Ao se fazer referência a um desses elementos especificamente é possível que, com a finalidade de se enumerar ou ressaltar características inerentes à referida esfera, seja dada ênfase a um aspecto ou outro. Mas é essencial que se adote uma compreensão sistêmica do quadro geral que se apresenta, sem fragmentar a realidade ou priorizar um elemento em detrimento de outro, até porque eles se inter-relacionam.

Nesse sentido, a sustentabilidade pressupõe uma relação equilibrada entre os elementos contidos no ambiente mais amplo, em que a ação humana afeta e é também afetada por eles. Sua concepção surgiu a partir do conceito de desenvolvimento sustentável, o qual passou por uma evolução desde que foi definido pela Comissão Mundial de Meio Ambiente e Desenvolvimento (World Commission on Environment \& Development - WCED) como um "estilo de vida que satisfaz as necessidades das gerações atuais, sem comprometer a satisfação das necessidades das gerações futuras" (WCED, 1987). Posteriormente, a busca pela sustentabilidade passou a ser entendida como um meio de "melhorar a qualidade de vida humana vivendo dentro da capacidade de carga que 
sustenta os ecossistemas" (IUCN, UNEP, WWF, 1991), ou ainda "viver com a capacidade regenerativa da biosfera" (Wackernagel et al., 2002).

Partindo-se de tais considerações, a sustentabilidade é definida como o equilíbrio entre o que é bom para as pessoas e suas comunidades e o necessário para a conservação dos recursos naturais e sociais, tendo como finalidade garantir a sobrevivência dos seres humanos do presente e do futuro (Corral-Verdugo, 2010). Trata-se de um paradigma que envolve o relacionamento do indivíduo com a natureza, com a temporalidade, com outras pessoas e, ainda, com autoridades e o próprio Estado (Bell, 2000, apud Kuhnen, 2011).

Diante de um cenário de crescentes preocupações socioambientais, as organizações passaram a ter que incorporar novas formas de atuação, apropriando-se do conceito de sustentabilidade. Ao longo desse processo, variadas definições surgiram para se referir a essa relação das organizações com a sustentabilidade, a qual pode ser interpretada sob diferentes rótulos, tais como ética de negócios, conformidade legal, filantropia, sustentabilidade, investimento na comunidade, gestão ambiental, respeito pelos direitos humanos, gestão de stakeholders, entre outros (Nizeyimana, 2011).

No entanto, alguns autores defendem que as ações organizacionais de cunho socioambiental não devem ser confundidas com práticas filantrópicas ou de caridade, mas devem ir além, considerando estratégias de sustentabilidade a longo prazo alinhadas à governança corporativa e à gestão empresarial (Cabestré, Graziadei \& Filho, 2008). Essa seria uma abordagem de responsabilidade socioambiental (RSA) das organizações, a qual será discutida posteriormente.

Com o crescimento populacional e o aumento do consumo, principalmente após a Revolução Industrial ocorrida no século XVIII, Strumpf (2013) destaca que as bases econômicas vêm gradativamente rompendo os limites do capital natural existente. Entende-se por capital natural a somatória dos benefícios tangíveis e intangíveis que os 
ecossistemas naturais fornecem e que são compartilhados por toda a sociedade humana (Andrade \& Romeiro, 2009). Strumpf atribui às organizações do setor privado a maior responsabilidade sobre a situação ecológica insustentável vivenciada atualmente e, segundo ele, também são elas que possuem maiores condições de prover soluções para uma remodelagem econômica considerando os limites impostos pelo capital natural.

Provavelmente o autor se refere ao modelo capitalista, que inicialmente buscava atender aos interesses dos proprietários do capital ou de seus stakeholders, incentivando o consumo. Nesse processo, a produção industrial tem como meta alcançar números cada vez mais elevados de resultados com o menor gasto financeiro possível - sem priorizar um ciclo limpo e responsável de produção. Este se relaciona à gestão de um processo produtivo comprometido com o menor impacto socioambiental possível, e ainda responsável pelo ciclo de vida do produto gerado.

Portanto, é de responsabilidade das grandes corporações rever o sistema produtivo que alimenta o capitalismo atual, na intenção de diminuir a geração de resíduos e contribuir efetivamente para a sustentabilidade. Tais esforços, no entanto, devem incluir os diferentes setores organizacionais, cada qual atuando de acordo com suas possibilidades de alcance do objetivo final de contribuir para a mudança necessária nesses tempos críticos de desequilíbrios e desastres socioambientais. Nesse contexto, as organizações devem comprometer-se com as consequências e os impactos de seus produtos e processos, no sentido de aceitar e assumir sua condição de agentes que fazem parte da sociedade que, além de abrigá-las, condicionam sua existência (Aligleri, Aligleri, \& Kruglianskas, 2009).

Há, no entanto, divergências teóricas a esse respeito. Alguns teóricos defendem a corresponsabilidade das organizações na solução dos problemas socioambientais, já que elas detêm poder político e habilidade de mobilizar recursos financeiros e tecnológicos para desenvolverem ações que podem inclusive ser replicadas pelos outros atores sociais 
(Young, 2004). Por outro lado, há aqueles de opinião contrária, que salientam a funçãoobjetivo das organizações na maximização dos lucros (Friedman, 1984), atribuem responsabilidade socioambiental a outras instituições que buscam o bem-estar social, tais como o governo, o Estado ou ainda organizações sem fins lucrativos (Machado Filho, 2006) e que salientam um exagero nas exigências externas de mercado que levam as organizações a adotarem o discurso de responsabilidade socioambiental de forma pouco clara quanto às suas reais contribuições (Henderson, 2001).

Ainda que uma organização seja apenas um dos atores nessa busca pela sustentabilidade, com uma atuação mais responsável frente às questões socioambientais, no processo de desenvolvimento econômico mundial a globalização muito contribuiu para o compartilhamento entre diferentes atores sociais de uma responsabilidade que antes era exclusiva do Estado (Bush \& Ribeiro, 2006). Essa reestruturação de papeis gerou a necessidade de se conhecer e debater mais sobre o tema.

Nesse sentido, no período compreendido entre o final da década de 1960 e meados da década de 1990 as questões socioambientais passaram a ser mais discutidas entre as nações, e atualmente é pauta obrigatória na maior parte dos encontros mundiais. Com o avanço da conscientização ecológica, foram criadas normas governamentais e órgãos reguladores sobre atividades organizacionais. Isto, aliado à pressão da opinião pública, passou a demandar mudanças em políticas e práticas organizacionais no sentido de atender à grande demanda por um posicionamento responsável sobre os problemas socioambientais.

No âmbito das organizações públicas, o Brasil tem buscado implementar a Agenda Ambiental na Administração Pública (A3P), cuja origem se deu a partir da Agenda 21, lançada na Conferência Rio 92. Trata-se de um programa iniciado no final da década de 1990, coordenado pelo Ministério do Meio Ambiente (MMA), com o objetivo de 
sensibilizar os gestores públicos para a importância das questões ambientais, estimulandoos a "incorporar princípios e critérios de gestão socioambiental em suas atividades rotineiras, levando à economia de recursos naturais e à redução de gastos institucionais" (MMA, 2009, p. 7).

Dessa forma, a A3P busca incorporar os princípios da responsabilidade socioambiental à Administração Pública. Para tanto, foi lançada uma cartilha com orientações para se colocar em prática o uso racional dos bens públicos e dos recursos naturais, envolvendo principalmente o consumo de papel, copos plásticos, energia e água no ambiente organizacional; a gestão adequada dos resíduos, relacionada à implementação de coleta seletiva e à destinação adequada de diferentes tipos de resíduos; a promoção da sensibilização e capacitação de todos os servidores públicos; a promoção da qualidade de vida no trabalho, com a implementação de ações que visem bem-estar, saúde e segurança no ambiente de trabalho; e a licitação sustentável, que prioriza a aquisição de bens e materiais, bem como contratações de serviços e projetos ambientalmente sustentáveis.

Ainda que a responsabilidade por tais problemas, muitas vezes desastrosos, bem como pelo alcance de objetivos visando a sustentabilidade do planeta seja de todos pessoas, comunidades, organizações, Estados e Governos - observa-se que o papel das organizações, tanto privadas quanto públicas, é de grande importância para o alcance das metas de sustentabilidade discutidas mundialmente. No entanto, mesmo adotando ações de RSA, as organizações não deixam de gerar impacto negativo, pois ele é inerente à sua existência. Considerando isto, é imprescindível que as iniciativas sejam realistas e dimensionem tanto o alcance das ações implementadas quanto suas limitações.

As ações demonstrativas da RSA não se referem a princípios preconizados, mas às práticas adotadas, as quais, de acordo com Ones e Dilchert (2012), podem ser caracterizadas como reativas, preventivas ou proativas, conforme o estágio em que a 
organização se encontra quanto aos esforços socioambientais empreendidos. Conforme destacado pelos autores, o primeiro estágio é caracterizado por ações que buscam atender legislações e normas, ou ainda requisitos sobre produtos e serviços, tratando-se de um comportamento de resposta da organização perante o que se espera dela. O segundo estágio enfoca a antecipação do impacto gerado, assumindo um papel não apenas reativo mas de redefinição de estratégias organizacionais para alcançar o objetivo proposto. $\mathrm{O}$ terceiro estágio pressupõe uma postura mais ativa de gestão, com a adoção voluntária de práticas que assegurem a sustentabilidade a longo prazo - o que é compatível com a concepção de sustentabilidade previamente exposta.

As ações organizacionais ora referidas são planejadas pelos gestores, mas a sua efetiva implementação depende da atuação dos trabalhadores, pois muitas delas pressupõem mudanças na organização do trabalho, nos processos e até mesmo nas ações cotidianas desses colaboradores, além das questões legais envolvidas no funcionamento organizacional. Dessa forma, os trabalhadores constituem os atores centrais que irão tornar realidade as políticas, ao colocarem em prática muitas das ações de RSA. Por esse motivo é importante conhecer o que os trabalhadores entendem por sustentabilidade, suas concepções, seu conhecimento sobre o tema, suas representações sobre esse fenômeno.

Nesse sentido, foi realizada uma pesquisa exploratória e descritiva com gestores e não gestores, com o objetivo de conhecer suas representações sobre a sustentabilidade. Considera-se que, além do conhecimento adquirido na própria Instituição onde eles trabalham, cada pessoa carrega consigo conhecimentos adquiridos fora desse contexto, provenientes de sua vivência pessoal. No entanto, para fins desta pesquisa, é de grande relevância a concepção adotada pela equipe gestora do Programa de Sustentabilidade implementado no local pesquisado, pois acredita-se que esse dado seja de grande 
influência não só na forma com que os trabalhadores compreendem o fenômeno, mas também na sua forma de agir de acordo com o que acreditam que ele seja.

\section{Método}

\section{Participantes}

Participaram desse estudo trabalhadores de uma instituição pública localizada em Brasília, sendo 25 não gestores e 11 membros do grupo gestor do Programa de Sustentabilidade da Instituição, totalizando 36 indivíduos (n). Destes, a maioria era do sexo masculino (55\%), solteira (53\%), com ensino médio completo (47\%), tem filhos $(61 \%)$, possui vínculo de terceirização (86\%) e não exerce cargo de chefia (83\%). A idade variou de 19 a $58 \operatorname{anos}(M=35, D P=10,5)$ e o tempo de trabalho na instituição, de 1 mês a 35 anos $(M=50,3, D P=75,4)$. A Tabela 1 apresenta os dados sociodemográficos e profissionais mais detalhados, considerando-se ainda a composição dos grupos de gestores $(\mathrm{N}=1)$ e não gestores $(\mathrm{N}=4)$.

\section{Tabela 1.}

Caracterização da amostra geral e dos grupos de gestores e não gestores

\begin{tabular}{|c|c|c|c|c|c|c|c|}
\hline \multirow{2}{*}{ Variável } & \multirow{2}{*}{ Item } & \multicolumn{2}{|c|}{ Gestores } & \multicolumn{2}{|c|}{ Não gestores } & \multicolumn{2}{|c|}{ Geral } \\
\hline & & $\mathrm{n}$ & $\%$ & $\mathrm{n}$ & $\%$ & $\mathrm{n}$ & $\%$ \\
\hline \multirow[t]{4}{*}{ Sexo } & Feminino & 6 & 54,5 & 10 & 40 & 16 & 44 \\
\hline & Masculino & 5 & 45,5 & 15 & 60 & 20 & 56 \\
\hline & Total & 11 & 100 & 25 & 100 & 36 & 100 \\
\hline & Sem resposta & 0 & 0 & 0 & 0 & 0 & 0 \\
\hline \multirow[t]{2}{*}{ Idade $^{1}$} & Variação & \multirow{2}{*}{\multicolumn{2}{|c|}{$\begin{array}{r}24 \text { a } 56 \text { anos } \\
0\end{array}$}} & \multirow{2}{*}{\multicolumn{2}{|c|}{$\begin{array}{r}19 \text { a } 58 \text { anos } \\
0\end{array}$}} & \multirow{2}{*}{\multicolumn{2}{|c|}{$\begin{array}{r}19 \text { a } 58 \text { anos } \\
0\end{array}$}} \\
\hline & Sem resposta & & & & & & \\
\hline \multirow[t]{4}{*}{ Escolaridade } & $\begin{array}{l}\text { Ensino médio } \\
\text { incompleto }\end{array}$ & 0 & 0 & 3 & 12 & 3 & 8 \\
\hline & Ensino médio completo & 1 & 9 & 16 & 64 & 17 & 47 \\
\hline & Graduação incompleta & 0 & 0 & 3 & 12 & 3 & 8 \\
\hline & Graduação completa & 1 & 9 & 0 & 0 & 1 & 3 \\
\hline
\end{tabular}




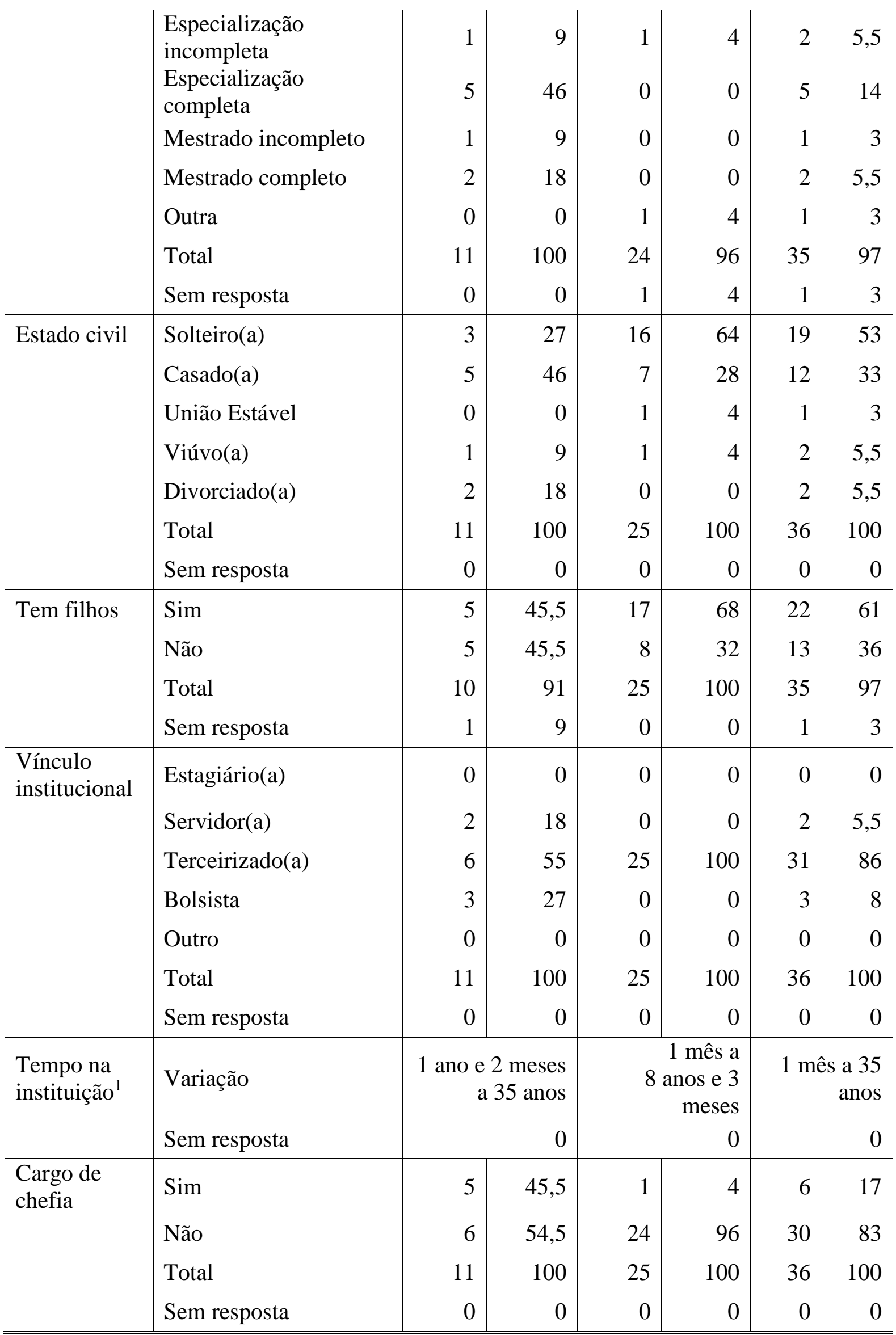

Nota: ${ }^{1}$ Pergunta aberta. 
Foram realizados 5 grupos focais ao todo, sendo 4 compostos integralmente por trabalhadores terceirizados da área de infraestrutura da Instituição, envolvendo as seguintes atividades: segurança, recepção, manutenção de ar condicionado, manutenção predial, limpeza, telefonia, jardinagem e transporte. O quinto grupo foi composto pelos gestores do Programa de Sustentabilidade e incluiu trabalhadores com diferentes tipos de vínculo (servidor, terceirizado e bolsista) que trabalham em diferentes setores da Instituição.

\section{Instrumentos}

Para o registro dos grupos focais foram utilizados dois gravadores digitais, caneta e papel. Além disso, para fins de caracterização da amostra, os participantes receberam um questionário com perguntas sociodemográficas e profissionais (sexo, idade, escolaridade, estado civil, se tem filhos, vínculo institucional, tempo de trabalho na instituição e se ocupa cargo de chefia). Foram trazidos para discussão questões relacionadas ao conceito de sustentabilidade, sendo a pergunta principal norteadora "O que vocês entendem por sustentabilidade?".

\section{Procedimentos de coleta de dados}

Inicialmente foi feito contato com o coordenador do Programa de Sustentabilidade da Instituição (PS), para apresentação da proposta de pesquisa. Após autorização do diretor da Instituição, foram agendados os dias e horários para a realização dos grupos focais na própria Instituição - o que também foi feito com a chefia do setor de infraestrutura a fim de que os trabalhadores fossem liberados para essa atividade.

Os grupos foram estruturados de acordo com a disponibilidade das pessoas quanto a tempo e interesse em participar da pesquisa, tendo sido uma amostragem nãoprobabilística. Formaram-se quatro grupos de não gestores, que aconteceram em dois dias 
do mês de agosto de 2016, sendo um em cada período do dia. Posteriormente, foi agendado o grupo focal com o grupo gestor do PS, que ocorreu em um dia desse mesmo mês, no período da tarde.

Todos os grupos se reuniram em uma sala disponibilizada pela própria Instituição, onde o ambiente era amplo e adequado para a atividade proposta. A equipe de pesquisa, que contou com a pesquisadora e uma assistente, chegava mais cedo e organizava o espaço, colocando as cadeiras em círculo e dispondo os gravadores em locais distintos. Os participantes chegavam no horário pré-agendado, voluntariamente. Após a acomodação de todos, a pesquisadora apresentava a pesquisa, pedia o consentimento para gravação de áudio e entregava o termo de consentimento livre e esclarecido (TCLE) ${ }^{1}$ aos trabalhadores. Concordando em participar, eles assinavam e respondiam o questionário sociodemográfico $^{2}$, e em seguida era colocada a questão norteadora para discussão do grupo (“O que vocês entendem por sustentabilidade?”). O tema era discutido livremente, com poucas intervenções da pesquisadora, que ao perceber o esgotamento da discussão finalizava agradecendo a participação de todos.

\section{Análise de dados}

Os dados gravados foram transcritos, de forma a permitir a análise dos dados coletados. As transcrições foram todas organizadas em um único arquivo de texto (corpus), sendo identificados por uma linha estrelada contendo as variáveis de identificação: identificação do grupo $(\mathrm{N}=5$, identificados por quatro asteriscos: ****GF_1, ****GF_2, ... ****GF_n) e classe dos trabalhadores, composta por duas modalidades (*tipo_1/.../ *tipo_2), sendo o tipo 1 o de não gestores e o tipo 2 o de gestores.

\footnotetext{
${ }^{1}$ O TCLE é apresentado no APÊNDICE A desta tese.

$2 \mathrm{O}$ questionário sociodemográfico respondido pelos participantes refere-se à parte 2 do Instrumento de Pesquisa que consta no APÊNDICE B desta tese.
} 
Os dados foram submetidos à análise lexical, com auxílio do Software Iramuteq. Trata-se de um programa informático gratuito que, conforme Camargo e Justo (2013), realiza uma classificação hierárquica descendente (CHD) que, além de permitir a análise lexical do material textual proveniente das transcrições dos grupos focais, fornece categorias (classes lexicais) caracterizados por um vocabulário específico e por segmentos de textos que compartilham tal vocabulário. Os resultados das análises evidenciam o que há de semelhante nos segmentos de texto de uma determinada categoria, bem como as diferenças desse vocabulário em relação aos segmentos de textos de outras categorias. Estas representam o contexto de sentido das palavras e podem refletir representações sobre o objeto de estudo, que neste caso é a sustentabilidade.

Os dados de caracterização da amostra foram tabulados em um banco de dados com o auxílio do Software Statistical Package for Social Sciences (SPSS) e submetidos a análises descritivas de frequência, porcentagem e variação de mínimo e máximo (para as perguntas abertas de idade e tempo de trabalho).

\section{Resultados e Discussão}

\section{Análise lexical}

Após submissão de um único corpus textual, que compreende a concepção dos participantes sobre o que é sustentabilidade, a classificação hierárquica descendente (CHD) reteve 264 segmentos de texto, 95,83\% do total do corpus analisado, e dividiu este em quatro classes (categorias) (Figura 1). 
Figura 1. Dendograma de classes sobre as representações de sustentabilidade, com a classificação hierárquica descendente

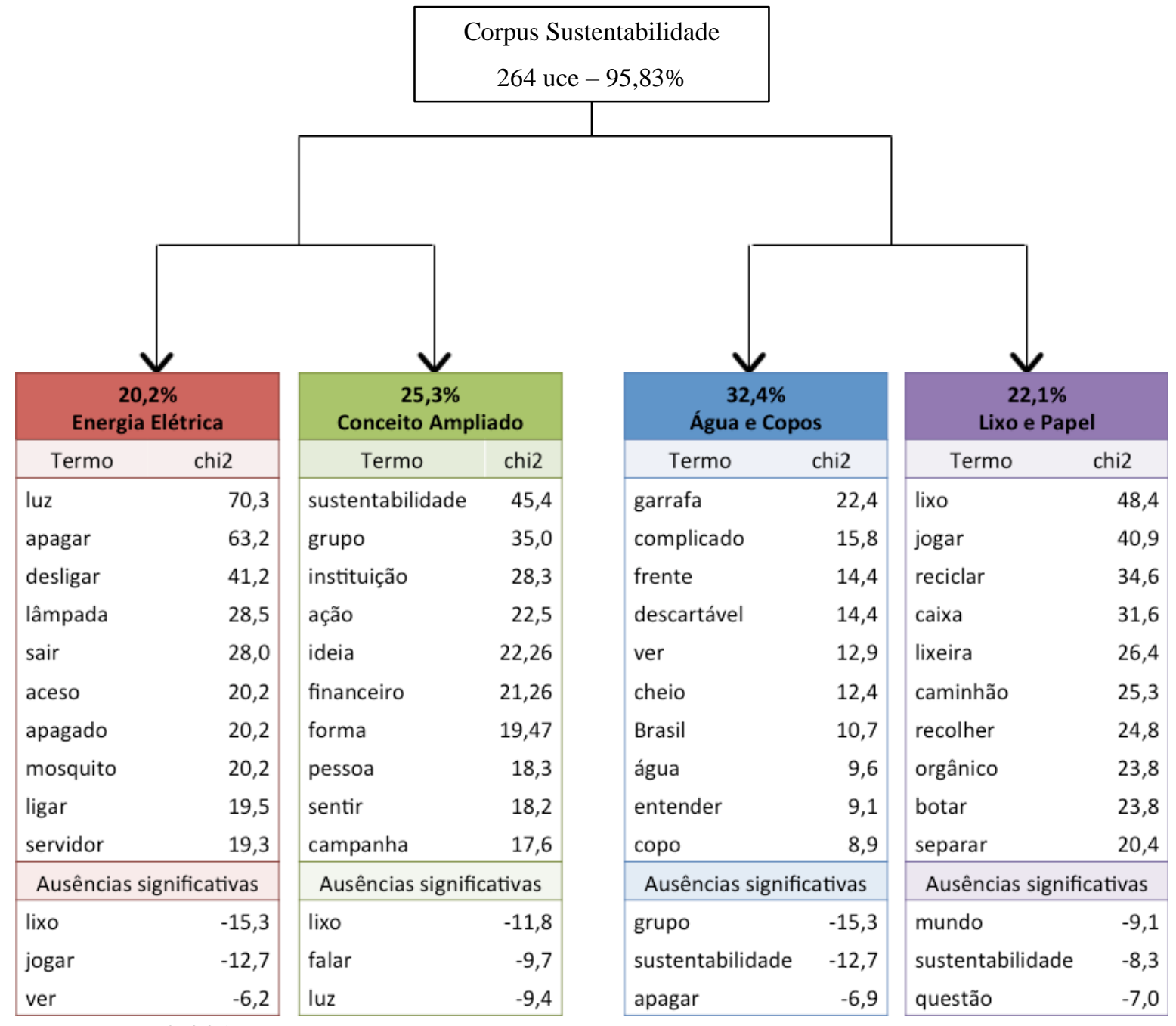

Nota: $p<0,001$

A primeira classe explica $20,2 \%$ da variância total do corpus selecionado e foi nomeada Energia Elétrica. A segunda classe, Conceito Ampliado, explica 25,3\% da variância. A terceira classe, Água e Copos Descartáveis, explica 32,4\% da variância, e a quarta classe, Lixo e Papel, explica 22,1\% da variância total. Esse resultados indicam a correlação entre as classes 1 e 2 e entre as classes 3 e 4, mas a força de associação entre elas não é informada pelo Iramuteq. São informados os termos em classificação hierárquica descendente, conforme os valores do Chi-quadrado, que se relacionam 
diretamente às classes geradas. Além disso, são indicadas as ausências significativas, com conteúdo não relacionado à classe em questão (termos com Chi-quadrado negativo).

Além dos termos mais significativos, os resultados apontam variáveis tanto na classificação hierárquica quanto nas ausências significativas. A classe 1 engloba predominantemente o conteúdo do texto referente à variável GF_3 $\left(X^{2}=25,31, p<0,001\right)$, de não gestores, e exclui conteúdos do GF_4 $\left(X^{2}=-4,18, p<0,05\right)$. A classe 2 inclui massivamente o conteúdo gerado pelo GF_5 $\left(X^{2}=106,3, p<0,001\right)$ e tipo_2 $\left(X^{2}=106,3, p\right.$ $<0,001)$, referentes especificamente ao grupo de gestores, e exclui os conteúdos do tipo_1 $\left(X^{2}=-106,3, p<0,001\right)$, de não gestores, e das variáveis GF_1 $\left(X^{2}=-14,7, p<0,001\right)$, GF_2 $\left(X^{2}=-5,9, p<0,05\right)$, GF_3 $\left(X^{2}=-8,72, p<0,01\right)$ e GF_4 $\left(X^{2}=-7,2, p<0,01\right)$. Já nas classes 3 e 4, embora não apresentem especificação de inclusão ou exclusão das variáveis nos resultados de classificação hierárquica pelo Chi-quadrado, há predominância de conteúdos das variáveis GF_1 e GF_2 (classe 3), e GF_4 (classe 4).

A classe Água e Copos (Classe 3), com maior quantidade de comentários (32,4\%), traz referências a estratégias de substituição de recursos e uso responsável de copos descartáveis, efetividade do PS, expectativa pessimista de futuro, desperdício de água, consciência da responsabilidade socioambiental, necessidade de maior fiscalização para a prática de comportamentos ecológicos e consciência temporal sobre as consequências dos comportamentos atuais no futuro. Tais elementos refletem os temas mais trabalhados pelo PS até o momento e que parecem possuir uma maior visibilidade na Instituição.

\section{Verbalizações}

“... eles tiraram os copos descartáveis e deram as canecas para nós...”

“... quando eu estou trabalhando aqui, eu pego o meu copo descartável, coloco o meu nome nele e fico ali tomando água muito tempo no mesmo copo... quase todo mundo aqui..."

“... aqui o pessoal pega pesado com a questão de sustentabilidade... aqui funciona, entendeu”. 
“... uma vez por semana lava, sem dó... aí eu vejo um desperdício de água, lavam até em cima, no teto... mas é muita água..."

Nas verbalizações aqui descritas observa-se que a organização conseguiu disseminar a ideia de sustentabilidade, o que se observa nas falas e nos atos diários dos funcionários, embora limitada ao consumo de água e energia. Ao mesmo tempo é observado que há desperdício de água na limpeza semanal, contrariando as orientações dadas e cobradas dos funcionários.

A classe 4, denominada Lixo e Papel, apresenta 22,1\% do total de comentários - a menos representativa, de acordo com o conteúdo trazido pelos grupos. Ela congrega elementos tais como coleta seletiva de lixo fora da instituição, ausência de separação do lixo na instituição, necessidade de estratégias para descarte responsável e coleta seletiva na instituição, incongruência estratégica do Programa de Sustentabilidade sobre descarte e coleta seletiva e percepção de comportamento não ecológico no trabalho.

\section{Verbalizações}

“... tem as caixas lá mas jogam tudo, é iogurte... não separam, eles jogam tudo na lixeira aí todo dia temos que trocar o saco que está todo melecado, aí não dá para aproveitar...”

"... tem um local que tem as duas lixeiras para a pessoa dividir lixo seco do lixo orgânico, só que tem outro local que é uma lixeira só para jogar tudo..."

"nas salas têm as caixas de reciclagem... o material está separado já, mas mistura tudo (...) porque vai tudo para o mesmo lugar".

“... vamos supor, nós temos o cuidado de recolher o lixo e estar sempre atentos, mas já tem outros que passam ali e já vão jogando... é incrível que tem gente que vê a lixeira ali e ainda tem coragem de jogar lixo no chão, é o que mais tem no banheiro, ninguém acerta a lixeira".

As verbalizações sobre lixo, separação do lixo seco e orgânico, indicam que a orientação dos gestores não está sendo cumprida por todos. Quem mais se preocupa com o lixo são os terceirizados que tem como ocupação a coleta e descarte do conteúdo das 
lixeiras. A ideia de sustentabilidade parece estar mais relacionada ao descarte e depósito do lixo sendo, assim, mais localizada e imediata.

Em oposição às classes 3 e 4 estão as classes 2 e 1 . A classe Conceito Ampliado (classe 2) apresenta $25,3 \%$ do total de comentários e se caracteriza massivamente pelas representações de gestores do PS, tendo agregado praticamente todo o corpus referente às variáveis GF_5/tipo_2 e excluído as demais. Compreende elementos referentes a relação entre sustentabilidade e saúde, definição integrada de sustentabilidade, falta de espaço para o PS na configuração institucional, bem como limitações para seu funcionamento e estratégias para divulgação e comunicação das ações do PS.

\section{Verbalizações}

“... esse conceito ampliado de saúde é definido pela composição dos elementos que tenham repercussão na nossa saúde... as questões envolvidas com a sustentabilidade têm uma relação direta com a saúde de cada um de nós..."

“... sustentabilidade tem a ver com qualidade de vida, com bem-estar, com deixar o mundo habitável mais tempo para mais pessoas".

“... temos um problema que é sério: nós não somos especialistas, ninguém que está aqui tem formação em meio-ambiente... também não temos uma estrutura organizacional para lidar diretamente com a sustentabilidade, então nós não temos um setor de sustentabilidade, é como se não houvesse investimento para isso".

“... o nosso canal de comunicação é bastante aberto, por exemplo tem pessoas que dão sugestão em um grupo fechado que temos no Facebook".

Nessas verbalizações já aparece uma concepção de sustentabilidade relacionada à saúde, qualidade de vida da população, meio ambiente e mundo mais habitável. Preocupação mais pertinente ao conceito de sustentabilidade que vem sendo utilizada. Além disso, levanta questões relacionadas diretamente ao funcionamento do Programa de Sustentabilidade, indicando não só a vantagem de existir abertura na comunicação entre os gestores e os demais funcionários, mas também algumas limitações e necessidades da equipe gestora em implementar o programa e as ações de RSA propostas por eles. 
Por fim, a classe 1, denominada Energia Elétrica, apresenta elementos relacionados a economia de energia elétrica, (falta de) engajamento no PS, igualdade no controle e na fiscalização para todos os funcionários, comportamento ecológico em outros contextos fora da instituição, críticas ao PS e preocupação com a visibilidade externa do PS. Observa-se que ao mesmo tempo em que refletem um dos temas já trabalhados pelo PS, o conteúdo dessa classe parece contrastar com o conteúdo da classe 2, Conceito Ampliado, representando uma forma de reação ao que é preconizado pelo grupo gestor do PS.

\section{Verbalizações}

“... Aqui eu costumo fazer isso: sair e apagar a (luz) do banheiro... mas engraçado que nem todo mundo faz isso. Entra, sai, deixa (acesa) e mesmo com aquele aviso bonitinho".

“... podia até haver um controle independente de ser servidor ou terceirizado".

“... a gente chega, abre as janelas, tenta acender o mínimo de luz possível”.

“... o que tem de pessoas que vêm de fora, que vêm de outros órgãos, mesmo aqui do DF, que ficam maravilhados com a estrutura... você ter recado para apagar a luz, para economizar papel, os copos, e temos que dar graças a Deus dessas pessoas que observam isso porque tem pessoas que nem observam".

Nessas falas observa-se principalmente a preocupação com o consumo de energia elétrica e, mais uma vez, a queixa por aqueles que não se preocupam com essa questão. De certa forma, também pode ser observada a queixa referente ao controle sobre o comportamento dos funcionários, que parece não ser igual para servidores e terceirizados. Também fica explícita a satisfação daqueles que percebem que as ações do Programa de Sustentabilidade da Instituição é percebido por pessoas externas que visitam ou frequentam esse local.

Além dos elementos constituintes de cada classe gerada, de acordo com a associação evidenciada entre elas é possível identificar elementos comuns implicados nessas associações. Considerando isto, as classes 1 e 2 compartilham elementos que 
refletem a motivação inicial da implementação do PS, a diferença do comprometimento de organizações públicas e privadas com a sustentabilidade e o engajamento dos trabalhadores nas ações propostas pelo PS.

Por sua vez, as classes 3 e 4 parecem compartilhar um maior número de elementos, tais como responsabilidade integrada no descarte e na coleta seletiva de lixo (incluindo orgânicos e recicláveis), percepção da necessidade de se oferecer educação ambiental na Instituição visando a mudança cultural desta, percepção de consequências negativas da falta de políticas públicas para coleta seletiva de lixo/resíduos e necessidade de controle sobre todo o processo de descarte do lixo na Instituição pesquisada.

A análise fatorial de correspondência nominal (AFCN), representada no dendograma que apresenta a relação entre as classes em uma distribuição espacial, de quatro quadrantes e dois eixos (Figura 2), sugere uma baixa correlação entre as classes 1 e 2. Por outro lado, as classes 3 e 4 apresentam-se bem integradas, o que sugere uma correlação alta entre elas. Também é possível perceber que a classe 2 está localizada de forma mais distinta das demais classes, que por sua vez encontram-se mais relacionadas entre si, ainda que mantenham sua distinção espacial. O Iramuteq não indica a força de associação entre as classes, ainda assim esse dendograma permite a visualização da forma com que elas se relacionam. 
Figura 2. Dendograma da disposição espacial da relação entre as classes.

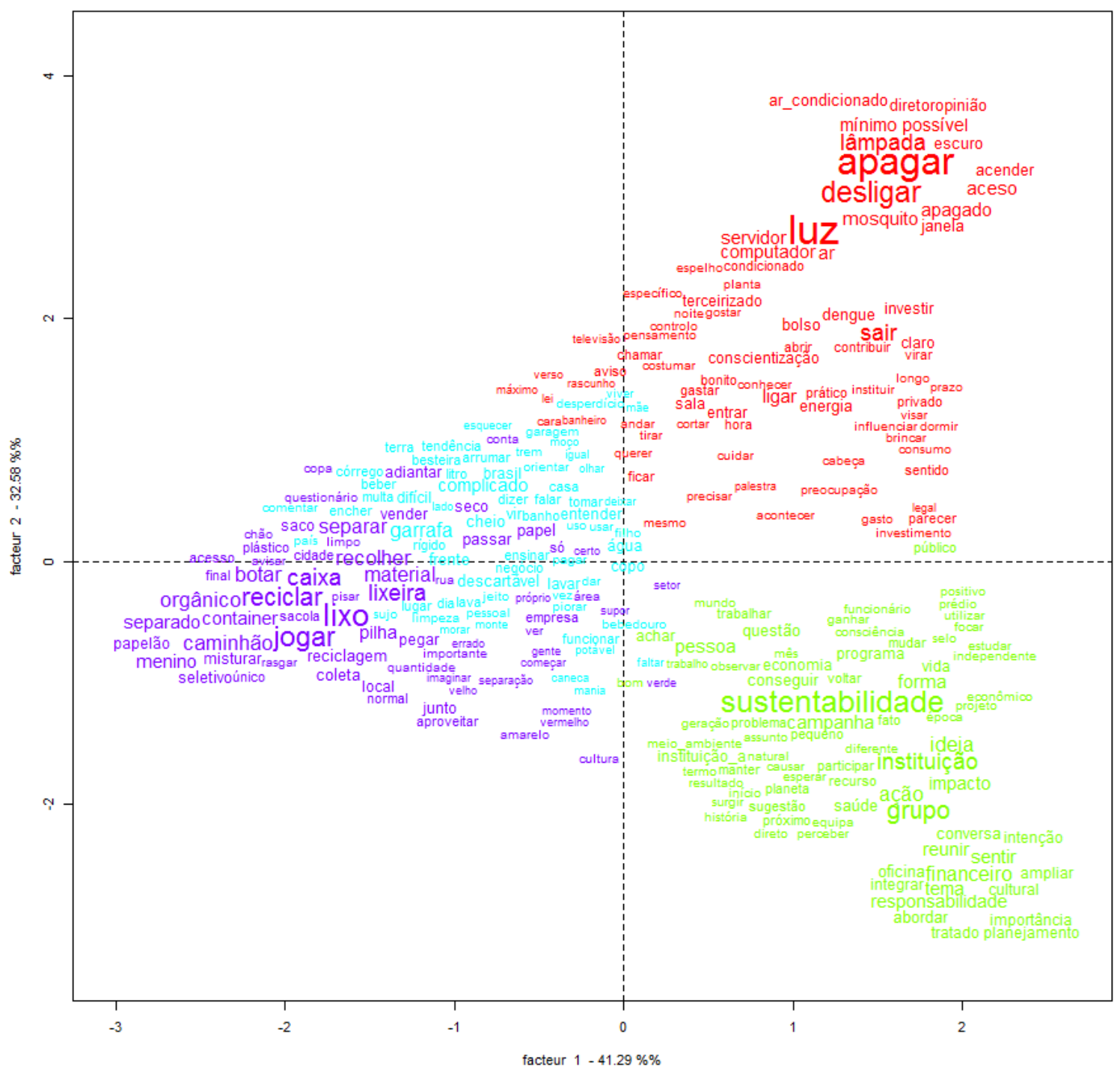

Observando-se a distribuição das classes nesse dendograma, percebe-se a alta correlação entre as classes 3 e 4, conforme já fora descrita, e um certo distanciamento entre as classes 1 e 2 - muito embora elas tenham sido correlacionadas pelo Iramuteq, conforme resultados apresentados na Figura 1. Esse dado sugere uma certa tensão entre essas classes, que se mostram distintamente localizadas uma em cada quadrante do dendograma. A classe 2 representa essencialmente o grupo de gestores (grupo focal 5), e em seu conteúdo fica explícito um conhecimento mais teórico e técnico sobre sustentabilidade. Já a classe 1 expressa mais fortemente um dos grupos de não gestores (grupo focal 3), composto por 
trabalhadores que atuam em diferentes atividades de infraestrutura na Instituição. Além da sua localização espacial demonstrar certa tensão em relação à classe 2 , seu conteúdo expressa uma reatividade a essa mesma classe, com elementos que remetem à relação de poder na Instituição, seja referente a gestores e não gestores, ou ainda entre servidores e terceirizados - conforme eles trazem em suas verbalizações.

A classe 3 congrega conteúdos de dois grupos focais, sendo que um deles foi constituído por trabalhadores que atuam em diferentes atividades (grupo focal 1) e o outro foi composto em sua grande maioria por funcionários da limpeza (grupo focal 2). Talvez por esse motivo essa classe se relacione mais com a classe 1 e a classe 4 . Esta última representa mais fortemente um dos grupos focais que também foi constituído em sua grande maioria por funcionários da limpeza (grupo focal 4). Considerando a representatividade de cada classe quanto à sua composição, de gestores e não gestores, e ainda os conteúdos congregados por elas, entende-se que cada classe representa elementos que são diretamente relacionados à atividade realizada pelos participantes dos grupos focais realizados neste estudo.

Dessa forma, torna-se compreensível a integração entre as classes 1, 3 e 4, que se apresentam mais próximas umas das outras, em oposição à classe 2. Considerando que esta última congrega massivamente o grupo de gestores do PS, o qual é praticamente desconsiderado na retenção textual das demais classes, entende-se que o discurso proferido pelos gestores da Instituição se distancia do discurso dos demais trabalhadores que não são gestores. Este dado sugere a dissociação do que o próprio PS apresenta como proposta e o que é compreendido pelos funcionários da Instituição, principalmente no que diz respeito ao que vem a ser a sustentabilidade propriamente dita. Significa dizer que a representação que os gestores têm de sustentabilidade ainda está bem distante do que os não gestores compreendem sobre esse tema. 


\section{Considerações Finais}

Esta pesquisa buscou identificar as representações de trabalhadores de uma Instituição pública brasileira sobre sustentabilidade. Observou-se que o discurso dessas pessoas se distanciou bastante do discurso dos não gestores. Os gestores apresentaram um conhecimento bastante teórico e mais aprofundado sobre o que seja sustentabilidade e o que ela envolve em termos gerais. Por sua vez, os não gestores parecem possuir uma concepção de sustentabilidade ainda incipiente, o que corrobora um elemento trazido por eles próprios sobre a necessidade de se promover educação ambiental na Instituição.

Isto porque os não gestores definiram a sustentabilidade considerando os temas trabalhados pelo Programa institucional, no caso relacionando o tema a ações de economia de água, copos descartáveis, papeis e energia elétrica. Ainda que eles trouxessem elementos em sua fala relacionados a outros aspectos de sustentabilidade, estes eram muitas vezes vinculados a sua vivencia fora do trabalho. Observou-se que os participantes sabem o que é a sustentabilidade e os aspectos relacionados a ela, mas de forma mais enfática eles trouxeram conteúdos relacionados ao que a instituição implementa como ação dentro do contexto de trabalho.

A promoção de educação ambiental na Instituição talvez seja uma forma da equipe gestora promover de forma mais eficaz os princípios de sustentabilidade que levariam a um maior engajamento dos trabalhadores em suas ações propostas, bem como em uma ampliação da representação de todos sobre a sustentabilidade - extrapolando os temas trabalhados categoricamente pelo PS. Além disso, é notória a necessidade da Instituição implementar efetivamente o Programa de Sustentabilidade que vem desenvolvendo as ações de RSA com os trabalhadores. Embora o Programa seja reconhecido por todos, há ainda a carência de uma gestão de sustentabilidade propriamente dita a ser incluída na cultura organizacional desse local. 
É preciso reconhecer que por se tratar de um estudo de caso os resultados aqui apresentados e discutidos não podem ser generalizados. Além disso, seria importante realizar os mesmos procedimentos com outros trabalhadores da Instituição, pois apenas aqueles lotados no setor de infraestrutura participaram dos grupos focais. É provável que trabalhadores de outros setores e outros vínculos institucionais apresentem diferenças nas representações que têm sobre o fenômeno aqui estudado. Portanto, uma limitação desse estudo foi justamente não envolver trabalhadores com variados tipos de vínculo e provenientes de diferentes setores da Instituição.

Sugere-se que sejam realizadas mais pesquisas dessa natureza, considerando essencialmente o ambiente organizacional, a fim de se identificar como trabalhadores de diferentes tipos de organização (pública, privada e outros) concebem a sustentabilidade. Ter esse conhecimento pode inclusive levar ao aprimoramento dos Programas implementados atualmente nas diferentes organizações brasileiras. Faz-se necessário ainda conduzir pesquisas em diferentes estados do país, uma vez que as dificuldades encontradas em cada região diferem de acordo com as características climáticas e culturais de cada área. 


\title{
MANUSCRITO 2
}

\section{Comportamento ecológico no ambiente organizacional: Evidências de validade de um instrumento de medida e o efeito preditor de variáveis sociodemográficas}

\begin{abstract}
Resumo
O comportamento ecológico tem sido investigado em diferentes contextos, e um que tem se mostrado de grande relevância para os estudos da área tem sido o local de trabalho, onde as pessoas passam grande parte de suas vidas. Com uma diversidade de definições encontradas na literatura, o comportamento ecológico (CE) pode ser entendido como uma conduta psicológica manifesta de responsabilidade com o meio ambiente, ou seja, um comportamento altruísta motivado pela ética baseada em princípios de sustentabilidade e qualidade de vida. Sua mensuração requer um instrumento capaz de capturar as ações explícitas dos indivíduos. Esta pesquisa apresenta dois estudos. O primeiro objetivou investigar evidências de validade de uma escala de CE no contexto organizacional. Composta inicialmente por 12 itens, ela foi aplicada a 158 trabalhadores de uma instituição pública brasileira. Após análises fatoriais exploratórias a melhor solução encontrada evidenciou uma escala unifatorial, composta por 9 itens, com características psicométricas satisfatórias e 22,7\% de variância explicada. Também foi identificada evidência de validade convergente, mas a validade discriminante não foi verificada. $\mathrm{O}$ segundo estudo objetivou testar o efeito preditivo de variáveis sociodemográficas sobre o CE no ambiente organizacional. Os resultados foram positivos para sexo e tendenciosamente positivos para idade. Os achados evidenciam a necessidade de aprimoramento da escala para a melhoria de suas características psicométricas, bem como a condução de mais estudos para identificar a adequação dessa medida em diferentes contextos organizacionais.
\end{abstract}

Palavras-chave: Comportamento ecológico; Organizações; Validade de medida

\section{Ecological behavior within organizational context: Validity evidence of a measure and the predictor effect of demographic variables}

\begin{abstract}
Ecological behavior (EB) has been investigated at various contexts, however workplace seems to be highly significant to this field studies. It is because people spend a great part of their lives at this place. With a variety of definitions found in the literature, EB can be
\end{abstract}


understood as a manifested psychological conduct with the environment. That is, an altruistic behavior motivated by ethics based on principles of sustainability and quality of life. It requires a measure capable in capture the explicit individuals actions. This research presents two studies. The first one aimed to investigate validity evidence of EB at an organizational context scale. Initially composed of 12 items, the measure was applied to 158 workers of a Brazilian public institution. After exploratory factor analysis the best result was a 9-item-scale with only one factor. Psychometric characteristics were satisfactory, and it explains $22,7 \%$ of variance. Also, was found convergent validity, though was not verified the discriminatory one. The measure must be improved and applied in more studies to demonstrate its adequacy at different organizational contexts. The second study aimed to test the predictor effect of demographic variables over EB at work. Results were positive to gender and tendentiously positive to age. Further studies must be conducted with these same variables and other different ones, for instance values and environmental beliefs, which could give relevant information about their relationship at the organizational context.

Keywords: Ecological behavior; Organizations; Measure's validity

\section{Introdução Teórica}

A sustentabilidade tem sido um tema abordado por diferentes áreas do conhecimento e seu paradigma, conforme Corral-Verdugo (2010), também tem sido utilizado em diferentes atividades - por exemplo, na política, nas ciências e nas artes. $\mathrm{O}$ autor destaca ainda que as variadas áreas de atuação profissional, bem como de produção do conhecimento, contribuem para a compreensão de aspectos particulares que constituem a sustentabilidade de uma forma global. Enquanto a economia determina fatores de produção e consumo para um estilo de vida sustentável, e a sociologia investiga relações de poder, instituições sociais e processos de socialização que afetam a sustentabilidade, a psicologia, por sua vez, determina os aspectos comportamentais, cognitivos e emocionais inerentes a esse estilo de vida (Corral-Verdugo, 2010). 
De acordo com Campos-de-Carvalho, Cavalcante e Nóbrega (2011), a relação entre as pessoas e o ambiente vem sendo objeto de estudo de várias áreas do conhecimento, tais como geografia social, arquitetura, planejamento urbano, engenharia ambiental, sociologia ambiental, biologia, ecologia humana, educação ambiental e psicologia ambiental. Segundo as autoras, esta última apresenta uma abordagem com maior ênfase nos processos psicológicos básicos, tais como cognição, desenvolvimento, personalidade e aprendizagem, e diferencia-se de outras áreas da psicologia que também estudam a relação pessoaambiente, tais como a psicologia social e do desenvolvimento, na medida em que inclui nessa relação as dimensões físicas ambientais.

A Psicologia Ambiental ocupa-se em estudar justamente a interação pessoaambiente, e de acordo com Corral-Verdugo (2010) busca saber como fatores situacionais afetam estilos de vida sustentáveis, variáveis disposicionais relacionadas à adoção desses estilos de vida e bem-estar pessoal. O autor descreve dois tipos de fatores situacionais (variáveis contextuais): natureza física, incluindo temperatura, acessórios tecnológicos, distância, presença ou ausência de um recurso natural; e de caráter normativo, tais como normas sociais, leis, valores coletivos e elementos culturais diversos. Portanto, também é de interesse da área identificar quais aspectos de natureza física e normativa levam o indivíduo a seguir uma conduta sustentável (Corral-Verdugo, 2010).

Tal tipo de conduta é proativo, ou seja, trata-se de um comportamento deliberado e intencional, e tem como finalidade cuidar dos recursos culturais e socioculturais para garantir o bem-estar presente e futuro da humanidade (Corral-Verdugo \& Pinheiro, 2004). Destaca-se, entretanto, que a conduta sustentável inclui ações de cuidado de pessoas e grupos, além da proteção do ambiente físico, e, por isso, diferencia-se da conduta proecológica, de cunho corretivo e de curto prazo (Corral-Verdugo, 2010). A primeira, portanto, possui um caráter mais amplo e sistêmico. Acrescenta-se ainda que esse tipo de 
comportamento inclui as dimensões psicológicas da sustentabilidade, indicando a importância de se conhecer os fatores cognitivos, emocionais e comportamentais relacionados à conduta sustentável (Kuhnen, 2011).

Relacionando-se tais dimensões psicológicas aos fatores que afetam a conduta sustentável - os quais são apresentados por Corral-Verdugo (2010) - é possível identificar que fatores comportamentais se relacionam às condutas adotadas (conduta proecológica geral, conduta de consumo austera, comportamentos altruístas, ações de cooperação e atos que demonstrem equidade). Já os fatores cognitivos estariam relacionados às variáveis disposicionais (orientação para o futuro, deliberação proambiental, visões de mundo em interdependência, apego a normas proambientais, afinidade com a diversidade e competência proambiental). Por sua vez, os fatores emocionais (afetivos) apresentam relação com as repercussões psicológicas (felicidade e restauração psicológica).

Pato e Campos (2011) identificaram uma diversidade de termos utilizados na literatura, com significados comuns, para se referirem a condutas de responsabilidade socioambiental (RSA). Mas as autoras destacam que o termo comportamento ecológico (CE) refere-se a condutas altruístas que não são automáticas nem podem ser impostas ao indivíduo. Embora definido como ações intencionais, dirigidas e efetivas, que atendem exigências tanto sociais quanto individuais e resultam em proteção do meio ambiente (Corral-Verdugo, 2010), outros autores defendem que o importante não é a intencionalidade consciente, mas a ação em si e seus efeitos positivos para a sustentabilidade (Pato \& Campos, 2011).

A preocupação com o meio ambiente e a implementação de práticas de RSA pelas organizações permitem o cumprimento de determinações e regulamentos legais impostos a elas. Além disso, tais iniciativas atendem demandas de mercado e apelos da sociedade por ações em prol da sustentabilidade. No entanto, é esperado das empresas um genuíno 
comprometimento com a sustentabilidade e, nesse sentido, que elas adotem ações socioambientais direcionadas tanto para o meio externo quanto para dentro do próprio contexto organizacional. Posto isto, a RSA deve ser traduzida em práticas ecológicas que também envolvam os trabalhadores e ainda considerem suas necessidades - o que pode resultar, por exemplo, no desenvolvimento de vínculos do indivíduo com a organização e o trabalho, avaliação favorável das políticas de gestão da empresa, bem-estar dos trabalhadores e, ainda, um melhor desempenho deles no trabalho.

Quanto ao envolvimento dos trabalhadores em ações planejadas para atingir um determinado fim, estudiosos do comportamento humano asseveram que um dos principais preditores é a percepção do indivíduo quanto à relevância dessa meta, além da percepção de sua capacidade de executar as ações (Bandura, 1994). Trazendo essa lógica interpretativa para o tema aqui discutido, é pertinente defender que as ações implementadas pela organização terão maior probabilidade de serem endossadas pelos funcionários na medida em que eles as considerarem relevantes. Isto é, as pessoas tendem a colaborar e efetivamente aderir às práticas socioambientais desenvolvidas pela organização quando as percebem como realmente importantes para a finalidade a que se propõem.

Outro aspecto relevante são as características específicas do ambiente de trabalho, que têm uma importante implicação para a adoção de comportamentos ambientais nesse contexto e acabam por determinar a significância de diversos fatores psicológicos para explicar tais comportamentos (Ruepert, Steg \& Keizer, 2015). A busca por tal explicação conta com uma diversidade de teorias sobre elementos que predizem o comportamento pro ambiental, tais como: teoria de valores, goal-framming theory, teorias que supõem que o comportamento é o resultado de análises de custo-benefício e teoria de hábitos.

Uma teoria que vem sendo muito utilizada na área é a do Novo Paradigma Ecológico (New Ecological Paradigm - NEP), que reflete crenças fundamentais sobre a 
relação entre o ser-humano e a natureza e apoia a ideia da humanidade como parte da natureza (ecocentrismo), em oposição ao paradigma social tradicional que defende que a humanidade foi criada para governar o resto da natureza (antropocentrismo) (Dunlap, Van Liere, Mertig \& Jones, 2000). Ruepert, Steg e Keizer (2015) defendem que a aceitação dessa nova proposta depende de valores pessoais, sendo que pessoas com fortes valores hedônicos ou egoísticos são menos propensas a apoiar o NEP e pessoas com fortes valores altruístas e biosféricos tendem a apoiar o novo paradigma proposto. Além disso, os autores salientam que estudos de comportamentos individuais têm validado a teoria que relaciona valores, crenças e normas de ambientalismo, mas em organizações ainda não foi testada sistematicamente, carecendo de mais estudos.

Pesquisas internacionais tem enfocado comportamentos proambientais de trabalhadores, estabelecendo relações entre eles e diversos outros fenômenos, tais como: afeto positivo e atitude proambiental, como preditores de comportamentos proambientais proativo e demandado (Bissing-Olson, Iyer, Fielding \& Zacher, 2013); estilo de liderança transformacional, especificamente ambiental, e comportamentos proambientais dos líderes como importantes influenciadores na mudança organizacional para uma ação mais ecológica (Robertson \& Barling, 2013); e monitoramento eletrônico de comportamentos de conservação de energia no ambiente de trabalho (Bolderdijk, Steg \& Postmes, 2013). Fazse necessário esclarecer aqui que, de acordo com Pato e Campos (2011), proambiental é um termo que, embora nominalmente seja diferente de ecológico, possui o mesmo significado deste - como tantos outros termos utilizados por pesquisadores dessa área.

No cenário nacional, estudos sobre comportamento ecológico têm sido desenvolvidos em diferentes contextos, considerando sua relação com outras variáveis, tais como valores pessoais e crenças ambientais As pesquisas demonstram que a relação entre valores pessoais e comportamento ecológico é significativamente mediada pelas crenças 
ambientais (Pato, 2004). Especificamente no contexto organizacional, o estudo da relação entre as mesmas variáveis demonstram que idade, crenças ecocêntricas, valores de universalismo e estimulação são preditores positivos de CE, enquanto poder e nível de escolaridade são preditores negativos desse fenômeno (Touguinha \& Pato, 2011).

A partir das considerações feitas, nesta pesquisa os comportamentos relacionados a aspectos socioambientais serão tratados como comportamentos ecológicos, em um sentido positivo da ação empreendida. Além disso, devido ao contexto de estudo ser um ambiente organizacional, entende-se que tais comportamentos podem ser, de alguma forma, incentivados nesse local. Entretanto, não se descarta a possibilidade desses comportamentos fazerem parte do cotidiano dos participantes em outros contextos, sejam privados ou públicos. Ainda assim, serão investigados apenas aqueles adotados quando estão trabalhando dentro da organização.

A pesquisa foi realizada em uma instituição pública brasileira que implementou um Programa de Sustentabilidade a partir do sucesso alcançado com uma campanha realizada no período de um ano. Essa campanha abordou os temas de economia de água, energia elétrica, papeis e copos descartáveis e vem sendo desenvolvida por uma equipe formada por trabalhadores de diferentes setores da instituição, com conhecimentos em áreas distintas. Serão apresentados dois estudos: o primeiro investigou evidências de validade de uma medida de CE no ambiente organizacional (Touguinha, 2008) e o segundo testa um modelo de predição para identificar os efeitos de variáveis sociodemográficas sobre o CE nesse contexto. Ambos são relatados a seguir. 


\section{ESTUDO 1}

\section{Objetivo de pesquisa}

Investigar evidências de validade de construto, convergente e discriminante de uma escala de comportamento ecológico no contexto organizacional.

\section{Método}

Considerando-se a base teórica sobre comportamento ecológico, buscou-se verificar empiricamente a adequação da medida do fenômeno direcionada ao contexto organizacional. Para tanto, foi realizada uma pesquisa correlacional de corte transversal, do tipo survey em uma Instituição pública brasileira que implementou um Programa de Sustentabilidade em 2014.

\section{Participantes}

Participaram da pesquisa 158 trabalhadores de um total de 440 funcionários (36\%) da unidade de uma instituição pública localizada em Brasília. Características sociodemográficas e profissionais são apresentadas na Tabela 1.

Tabela 1.

Caracterização da amostra

\begin{tabular}{l|l|r|r}
\hline \multicolumn{1}{c|}{ Variável } & \multicolumn{1}{c|}{ Item } & $\mathrm{N}$ & \multicolumn{1}{c}{$\%$} \\
\hline \multirow{2}{*}{ Sexo } & Feminino & 78 & 49,4 \\
& Masculino & 80 & 50,6 \\
& Total & 158 & 100 \\
& Sem resposta & 0 & 0 \\
\hline Idade $^{1}$ & 17 a 67 anos & 157 & 99,4 \\
& Sem resposta & 1 & 0,6 \\
\hline Escolaridade & Ensino médio incompleto & 8 & 5,1 \\
& Ensino médio completo & 20 & 12,7
\end{tabular}




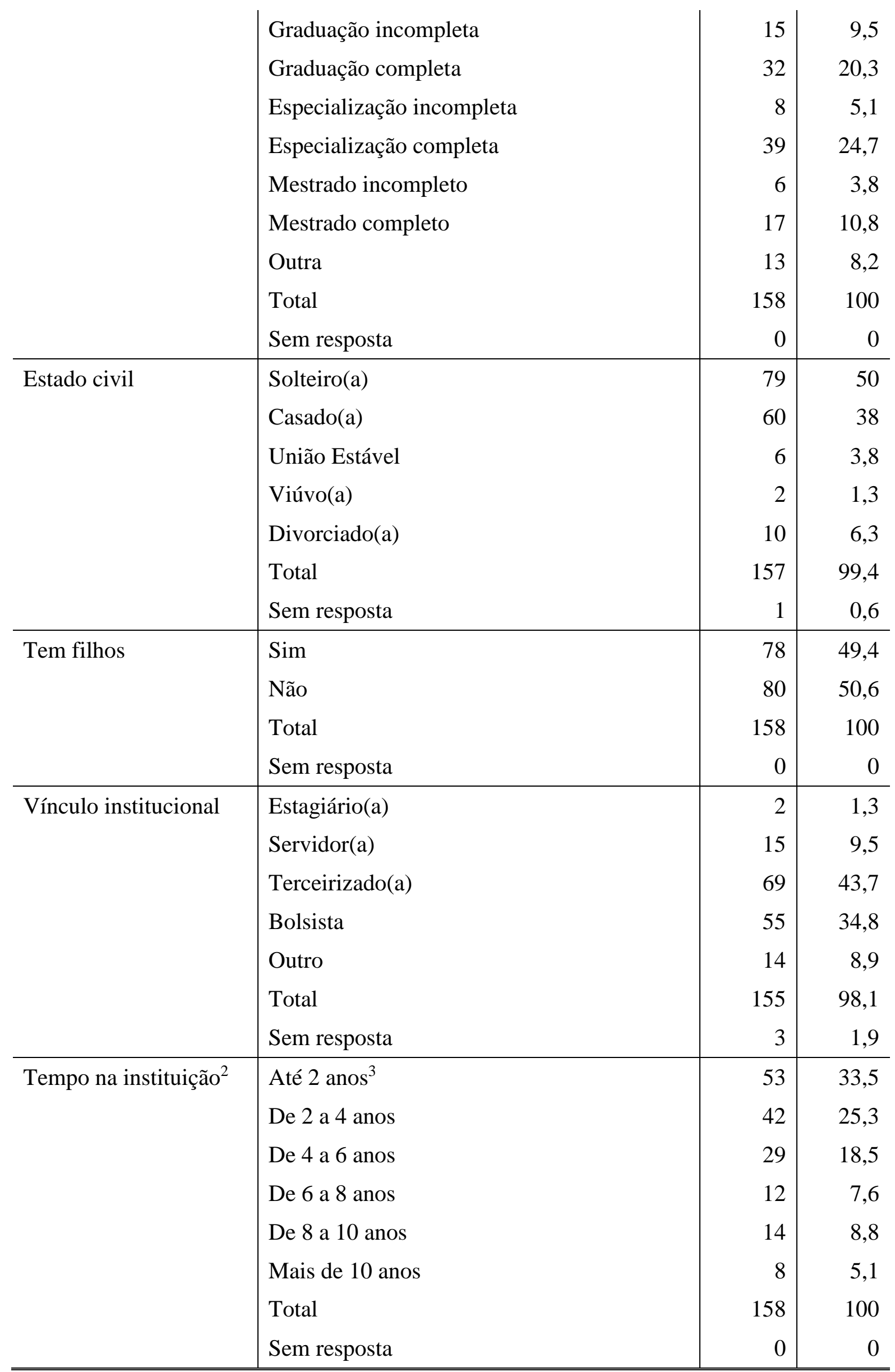




\begin{tabular}{l|l|r|r}
\hline \hline Cargo de chefia & Sim & 14 & 8,9 \\
& Não & 141 & 89,2 \\
& Total & 155 & 98,1 \\
& Sem resposta & 3 & 1,9 \\
\hline \hline
\end{tabular}

Nota: ${ }^{1}$ Pergunta aberta. ${ }^{2}$ Pergunta aberta que foi categorizada posteriormente. O tempo na instituição variou de 6 meses a 38 anos e 8 meses. ${ }^{3}$ Foi considerado esse período a partir de 6 meses, que é o tempo mínimo que o trabalhador precisa para se familiarizar com normas e políticas organizacionais.

\section{Instrumento}

$\mathrm{O}$ instrumento de pesquisa ${ }^{3}$ utilizado foi formatado em um único documento em papel e continha a Escala de Comportamento Ecológico em Ambiente Organizacional, um questionário sociodemográfico e profissional e uma pergunta específica sobre consumo de copos descartáveis.

\section{Escala de Comportamento Ecológico em Ambiente Organizacional-ECEAO}

Esta escala foi adaptada ao contexto organizacional por Touguinha (2008) a partir da escala de comportamento ecológico elaborada por Pato e Tamayo (2006). A medida é unifatorial, do tipo Likert com cinco pontos $(1=$ Nunca, $2=$ quase nunca, $3=$ algumas vezes, $4=$ muitas vezes, $5=$ Sempre) e possui 12 itens referentes a comportamentos ecológicos no contexto organizacional $(\alpha=0,77 ; 23 \%$ de variância explicada), mais especificamente relacionados a comportamentos de limpeza na instituição, economia de água, energia e papel. Além destes, foram mantidos os itens de desejabilidade social (DS) incluídos por Touguinha, considerando-se a natureza do tema pesquisado e das características do contexto dos participantes, totalizando 15 itens.

Algumas adaptações foram feitas nessa escala para sua utilização no presente estudo: a redação do item 3 (Procuro evitar desperdício de água) foi alterada, sem alterar o

\footnotetext{
${ }^{3} \mathrm{O}$ instrumento utilizado nessa pesquisa é apresentado no APÊNDICE B desta tese.
} 
sentido da afirmação, para 'Evito desperdiçar água'; o item 13 (Não me preocupo com o desperdício de papel) foi retirado por apresentar ambiguidade de compreensão ao ser avaliado de acordo com a escala de resposta (nunca a sempre). A escala ficou, portanto, composta por 14 itens, sendo 11 de comportamento ecológico e 3 de DS.

\section{Questionário sociodemográfico e profissional}

Foram incluídas no questionário algumas perguntas sociodemográficas e profissionais para caracterização da amostra, tais como sexo, idade, escolaridade, estado civil, se a pessoa tem filhos, o vínculo institucional, tempo de trabalho na instituição e se ocupa cargo de chefia. Além destas havia também uma pergunta específica sobre consumo de copos descartáveis ('Quantos copos descartáveis você usa por dia no seu trabalho?').

\section{Procedimentos de coleta de dados}

Inicialmente foi feito contato com o coordenador do Programa de Sustentabilidade da Instituição, que colocou-se disponível para contribuir com o estudo. Antes da realização da coleta foi veiculada uma mensagem institucional, a fim de informar a todos sobre a realização dessa pesquisa na Instituição. A coleta de dados foi realizada no período de 15 a 19 de agosto de 2016, contando com a pesquisadora e duas assistentes de pesquisa, uma externa e uma interna à Instituição. Salienta-se que a atuação da assistente interna foi de grande relevância na abordagem e na sensibilização dos trabalhadores para participarem da pesquisa. Nesse período, a equipe visitou todos os setores da Instituição, apresentando a pesquisa e solicitando a participação voluntária de todos.

Com poucas exceções, a grande maioria dos trabalhadores concordou em participar. Nesses casos, foi entregue o termo de consentimento livre e esclarecido (TCLE) em duas vias e o participante deveria assinar e devolver uma via à equipe, que então entregava o 
questionário de pesquisa e mais tarde, no mesmo dia e/ou turno, retornava para recolher. Esse procedimento foi realizado em cada setor, buscando-se garantir a maior representatividade da Instituição possível. Buscou-se, portanto, garantir uma amostra representativa da organização, o que resultou em $36 \%$ da população organizacional.

\section{Análise de dados}

Os dados coletados foram analisados com auxílio do software estatístico Statistical Package for Social Sciences (SPSS), versão 20. Inicialmente foi feita a limpeza do banco de dados, com o tratamento de missings e outliers univariados (boxplots) e multivariados (Distância Mahalanobis) e a verificação da normalidade de distribuição dos dados (índices de assimetria e curtose; testes de Kolmogorov-Smirnov e Shapiro-Wilk), para então se proceder às demais análises.

Para a identificação de evidências de validade de construto, a Escala de Comportamento Ecológico no Ambiente Organizacional foi submetida à análise fatorial exploratória (AFE). Para verificação de evidências de validade convergente e discriminante, foram realizadas correlações bivariadas entre as variáveis $\mathrm{CE}$ e número de copos utilizados no trabalho, bem como CE e desejabilidade social, respectivamente.

\section{Resultados}

Inicialmente, investigou-se o padrão geral de respostas no banco de dados, para se verificar a ocorrência de dados ausentes (missings) sistemáticos ou dados extremos (outliers) que pudessem fragilizar as análises pretendidas. Foram identificados menos de 5\% de missings, o que levou à decisão de tratamento desses dados com a substituição pela média. As variáveis foram então transformadas em escores z para a identificação de outliers, sendo que os univariados foram investigados por meio dos boxplots e os 
multivariados, pela distância Mahalanobis $\left(D^{2}\right)$ para 11 graus de liberdade $\left(X^{2}=31.264 ; p\right.$ $<0,001$ ). Não foram feitas transformações, tendo-se optado por manter os univaridados (já que somavam menos de $5 \%$ dos casos) e pela retirada de três casos multivariados identificados.

Os índices de assimetria e curtose dos dados apresentaram alguns desvios acima de 2,0, indicando ausência de normalidade univariada da distribuição (Miles \& Shevlin, 2001), assim como testes de Kolmogorov-Smirnov e Shapiro-Wilk $(p<0,05)$. No entanto, sabe-se que a análise fatorial é robusta à normalidade (Pasquali, 2005). Portanto, tais resultados não inviabilizam a realização das análises que se seguem.

\section{Evidências de validade de construto}

Após a limpeza do banco de dados, procedeu-se à investigação da fatorabilidade da matriz. O índice de adequação da amostra $(K M O=0,63)$ foi aceitável (Field, 2013), o teste de esfericidade de Bartlett mostrou-se significativo $\left(X^{2}=219,366, d f=55, p<0,001\right)$. Posteriormente, para a identificação do número adequado de fatores a serem extraídos do total de itens da escala, observou-se a magnitude dos eigenvalues, conforme critério de Kaiser, bem como o gráfico de sedimentação (scree plot), de acordo com o critério de Catell. Ambos indicaram a possibilidade de extração de quatro fatores, o que foi ainda corroborado pela análise paralela de Horn. No entanto, após um processo iterativo de extrações buscando-se identificar a solução mais ajustada sob uma perspectiva tanto teórica quanto psicométrica - pelo método dos eixos principais $(P A F)$ com rotação Promax, pressupondo a existência de fatores oblíquos, mas reconhecendo a sua especificidade -, a melhor solução encontrada foi de um único fator.

Considerando-se a magnitude da carga fatorial acima de 0,30 (Tabachnick \& Fidel, 2007), dois itens não apresentaram carga fatorial suficiente e foram retirados. Observa-se, 
entretanto, que as cargas fatoriais dos itens que permaneceram na escala são superiores a 0,41, remetendo a uma boa representação do fenômeno mensurado. Após a retirada desses itens, foi realizada nova análise fatorial, cuja solução final é apresentada na Tabela 2, que contém as cargas fatoriais de cada item (em ordem decrescente), suas comunalidades $\left(h^{2}\right)$ e os índices de confiabilidade encontrados.

\section{Tabela 2.}

Cargas fatoriais e comunalidade dos itens da Escala de Comportamento Ecológico em Ambiente Organizacional

\begin{tabular}{l|c|c}
\hline \multicolumn{1}{c|}{ Enunciado do Item } & $\begin{array}{c}\text { Cargas } \\
\text { fatoriais }\end{array}$ & $h^{2}$ \\
\hline 8. Evito desperdiçar energia elétrica. & 0,69 & 0,47 \\
4. Coloco na caixa de coleta seletiva os papéis que podem ser reciclados. & 0,61 & 0,37 \\
7. Mobilizo meus colegas para reduzir o consumo de energia. & 0,57 & 0,32 \\
3. Evito desperdiçar água. & 0,53 & 0,28 \\
5. Aproveito para rascunho o outro lado do papel usado. & 0,48 & 0,23 \\
1. (invertido) Jogo todo tipo de lixo em qualquer lixeira. & 0,46 & 0,21 \\
2. Apago a luz quando sou o último a sair da sala. & 0,44 & 0,19 \\
9. Converso com meus colegas sobre defesa do meio ambiente. & 0,42 & 0,18 \\
6. Jogo copo descartável no coletor próprio para ele. & 0,41 & 0,17 \\
\hline
\end{tabular}

Alpha de Cronbach: 0,70

Total de variância explicada: $22,7 \%$

Como resultado, obteve-se então uma escala unifatorial de comportamento ecológico em ambiente organizacional, composta por 9 itens $(\alpha=0,70)$ que representam comportamentos relacionados ao uso consciente de água, energia e papel, ativismo e descarte de resíduos (lixo e papel) na instituição e que explicam $22,7 \%$ de variância do fenômeno. O item 1 foi recodificado, uma vez que estava redigido em sentido negativo, ou seja, como um comportamento não ecológico. Dos 13 itens da ECEAO de Touguinha (2008), 9 apresentaram carga fatorial significativa e contribuíram para a explicação do fator. Salienta-se que, embora o número de itens da escala seja igual, este resultado não foi 
exatamente o mesmo encontrado por Touguinha. Para maiores detalhamentos de tais diferenças sugere-se a leitura do estudo da autora.

\section{Evidências de validade convergente}

As variáveis comportamento ecológico e número de copos descartáveis usados diariamente no trabalho foram submetidas à correlação bivariada de Pearson. O resultado evidenciou uma correlação negativa $(r=-0,20, p<0,05)$, indicando que quanto mais as pessoas emitem um comportamento considerado ecológico no seu local de trabalho, menos copos descartáveis elas utilizam nesse contexto. Fica evidenciada, assim, a validade convergente da ECEAO.

\section{Evidências de validade discriminante}

Para a verificação da validade discriminante da medida, o fator comportamento ecológico foi correlacionado com a desejabilidade social dos participantes. Realizou-se o teste de correlação bivariada de Pearson, cujo resultado evidenciou uma alta correlação positiva entre as variáveis $(r=0,42, p<0,05)$. Isto indica que as variáveis não são bem discriminadas entre si, não evidenciando, portanto, a validade discriminante da medida.

\section{Discussão}

Este estudo teve como objetivo a busca por evidências de validade da Escala de Comportamento Ecológico em Ambiente Organizacional (ECEAO). As evidências de validade de construto encontradas corroboram os dados encontrados por Touguinha (2008), exceto pelo fato de não possuir a correspondência de um dos itens retidos nas análises fatoriais exploratória realizadas nos dois estudos. No entanto, tal fato não invalida a capacidade da medida em capturar o fenômeno em questão. 
Os resultados da análise fatorial exploratória realizada no estudo aqui relatado evidenciaram a validade de construto da medida, mas reforça-se a necessidade do aprimoramento da escala, com a inclusão de novos itens que reflitam outros tipos de comportamentos inerentes à vivência laboral nas organizações. Além disso, é preciso que mais estudos sejam desenvolvidos com a ECEAO, a fim de se obter evidências sobre a relação entre comportamento ecológico e outras variáveis, tais como valores, atitudes, crenças, engajamento, ou as próprias características sociodemográficas e profissionais dos trabalhadores.

Também foram encontradas evidências de validade convergente, mas a validade discriminante não foi verificada. Sugere-se, portanto, a realização de futuras pesquisas considerando outras variáveis para se atestar essa distinção do fenômeno. Além disso, torna-se relevante uma ampliação da pesquisa realizada, a fim de envolver mais participantes e talvez se conseguir maior variação da variável ativismo ambiental.

\section{ESTUDO 2}

\section{Objetivos de pesquisa}

\section{Objetivo Geral}

Identificar se as diretrizes institucionais de sustentabilidade afetam o comportamento ecológico dos trabalhadores nesse contexto.

\section{Objetivos específicos}

- Mapear as ações de RSA adotadas pela instituição pesquisada;

- Verificar a relação entre variáveis sociodemográficas e profissionais e o comportamento ecológico dos trabalhadores dessa instituição; 


\section{Método}

Para o alcance dos objetivos propostos foi realizada uma pesquisa correlacional de corte transversal. Foram analisados relatórios de sustentabilidade fornecidos pela Instituição e, posteriormente, realizada uma pesquisa do tipo survey com os demais trabalhadores daquele local.

\section{Participantes}

Participaram da pesquisa 158 trabalhadores da unidade de uma instituição pública localizada em Brasília. Características sociodemográficas e profissionais são especificadas na Tabela 1, a qual já foi apresentada no Estudo 1.

\section{Instrumentos}

Para esta pesquisa foram utilizados dados referentes às ações de RSA adotadas pela Instituição e que constam em seus relatórios de sustentabilidade e um questionário composto pela Escala de Comportamento Ecológico em Ambiente Organizacional (ECEAO) (Touguinha, 2008), por questões sociodemográficas e profissionais, além de duas perguntas sobre ativismo ambiental.

\section{Procedimentos de coleta de dados}

Após o contato inicial com o gestor responsável por coordenar o Programa de Sustentabilidade da Instituição pesquisada, foram estabelecidos os melhores dias/horários para a realização da coleta de dados com os demais trabalhadores da Insituição. A equipe de pesquisa, composta pela pesquisadora responsável e duas assistentes, foi ao local e fez a coleta pessoalmente, com lápis e papel. 
Os trabalhadores eram abordados em seu posto de trabalho, a pesquisa era brevemente apresentada e solicitava-se a participação de todos. Aqueles dispostos a participar deveriam assinar o termo de consentimento livre e esclarecido e depois recebiam o questionário. A equipe deixava o material com os participantes e passava depois recolhendo, no mesmo dia, colocando todo o material em envelopes pardos.

Todos os setores institucionais foram visitados pela equipe no período de uma semana, na intenção de se obter a maior representatividade da Instituição possível. Buscouse, portanto, uma amostra estratificada, com a participação de no mínimo $30 \%$ dos trabalhadores de cada setor.

\section{Análise de dados}

Os relatórios foram avaliados, buscando-se realizar um mapeamento das informações necessárias para a caracterização do Programa de Sustentabilidade da Instituição pesquisada em termos de ações de RSA empreendidas.

Os dados dos questionários foram analisados com auxílio do programa estatístico Statistical Package for Social Sciences (SPSS), versão 20. Iniciou-se com a limpeza do banco de dados, com a verificação de missings e outliers (uni e multivariados), e investigação da normalidade de distribuição dos dados - por meio dos escores $\mathrm{z}$ de skewness e kurtosis e pelos testes de Kolmogorov-Smirnov $(K-S)$ e Shapiro-Wilk.

Para o alcance dos objetivos propostos, foram realizadas análises descritivas (média, desvio padrão) e de regressão logística entre variáveis sociodemográficas/profissionais (variáveis antecedentes) e o fator de CE (variável consequente). Para verificar se o tamanho da amostra é adequado para as análises aqui propostas, considerando-se o tamanho de efeito, o poder estatístico e a significância, foi utilizado o software $\mathrm{G}^{*}$ Power 3.1, com análise feita a priori. 


\section{Resultados}

\section{O Programa de Sustentabilidade}

A Instituição pesquisada é de natureza pública e está localizada em Brasília. Tratase de uma das unidades da Instituição, cuja atuação envolve pesquisas (não laboratoriais). Em 2014 a alta gestão demandou ações de RSA, e foi implementada uma Campanha de Sustentabilidade. O principal objetivo era diminuir despesas com água, energia elétrica, papeis e copos descartáveis e ainda incentivar o uso consciente e responsável de tais recursos. Ao longo de um ano foram realizados quatro ciclos de ações pontuais, envolvendo justamente temas relacionados aos recursos supracitados. Foram realizadas palestras, oficinas e dinâmicas sobre temas específicos para públicos específicos que trabalham diretamente com o recurso em questão. O resultado foi além das expectativas iniciais, o que levou a direção da Instituição a consolidar a campanha como um Programa de Sustentabilidade em 2015.

Além do coordenador responsável pelo Programa há uma equipe de pessoas envolvidas diretamente com a gestão dele. São funcionários da Instituição que trabalham em setores diversos e que se reúnem com certa frequência para propor estratégias e tomar decisões - o que é feito de forma compartilhada entre eles. Essa equipe gestora se subdivide em três grupos: um que define as ações que serão realizadas, outro grupo de monitoramento e outro grupo de relatoria. No entanto não há um especialista em meio ambiente ou outra área afim e que tenha expertise para a implementação do Programa de Sustentabilidade na Instituição. Além disso, os membros da equipe gestora possuem outras atividades em seus setores de trabalho, tornando escasso o tempo de dedicação à gestão da sustentabilidade na Instituição - além de não receberem especificamente para realizar essa atividade, que acaba sendo uma tarefa a mais que eles devem desempenhar em seu trabalho e não haver destinação de orçamento específico para esse Programa. 
Atualmente o foco do Programa continua recaindo sobre ações de economia de água, energia elétrica, papel e copos descartáveis. Mas além disso ele procura relacionar esses temas com questões de saúde pública, tal como o combate do mosquito Aedes Aegypti - que este ano foi central em todo o país em decorrência de epidemias provenientes da picada desse mosquito. Os resultados das ações de sustentabilidade empreendidas na Instituição foram até então positivos, mas há demandas em se trabalhar outros temas, tais como o descarte e coleta seletiva de lixo/resíduos, que ainda não foram efetivamente implementados nesse local.

\section{Comportamento ecológico no trabalho e sua relação com características}

\section{sociodemográficas}

Foram entregues 205 questionários aos trabalhadores da Instituição pesquisada, mas foram devolvidos 195, configurando uma taxa de retorno de 95\%. Retirou-se da amostra aqueles entregues com menos de 50\% das questões respondidas, os respondidos por trabalhadores que estão há menos de seis meses na Instituição - tempo mínimo necessário para eles se apropriarem das normas e políticas organizacionais -, aqueles que foram entregues com a informação sobre tempo de trabalho na instituição em branco (pelo motivo já exposto) e os identificados como casos extremos multivariados. Ao todo foram retirados 37 questionários, resultando em uma amostra de 158 participantes de um universo de 440 trabalhadores, ou seja, $36 \%$ da população. Os resultados serão apresentados de acordo com os objetivos propostos, para uma melhor organização das informações e também para facilitar sua leitura e compreensão.

Os testes de normalidade (escores z de skewness e kurtosis, K-S e Shapiro-Wilk) indicaram uma distribuição não normal dos dados. No entanto, o efeito de problemas de normalidade costumam estar diretamente relacionados ao tamanho da amostra (Hair, 
Black, Babin, Anderson \& Tatham, 2009). Nesse sentido, foi verificada a adequação do tamanho da amostra do presente estudo considerando-se um tamanho de efeito de 0,5 , um alpha de 0,001 e um poder estatístico de 0,95 - índices estes considerados satisfatórios resultando em uma amostra mínima de 79 participantes para as análises aqui propostas. A partir desses dados, procedeu-se às análises estatísticas pertinentes ao estudo.

Para alcançar o objetivo geral da pesquisa, que consiste em identificar se as diretrizes estabelecidas para o Programa de Sustentabilidade implementado pela Instituição pesquisada têm algum efeito sobre o comportamento ecológico dos seus trabalhadores nesse contexto, foram realizadas análises descritivas (média e desvio padrão) e de correlação bivariada. Além do fator único da ECEAO, foram feitas análises dos itens de DS, a fim de se estimar a influência desse fator no CE investigado. Os resultados são apresentados na Tabela 3.

Tabela 3.

Resultados descritivos de comportamento ecológico no ambiente organizacional $e$ desejabilidade social

\begin{tabular}{l|c|c}
\hline \multicolumn{1}{c|}{ Variável } & M & DP \\
\hline Comportamento ecológico no ambiente organizacional & 3,74 & 0,49 \\
\hline 2. Apago a luz quando sou o último a sair da sala. & 4,61 & 0,79 \\
3. Evito desperdiçar água. & 4,48 & 0,75 \\
8. Evito desperdiçar energia elétrica. & 4,34 & 0,82 \\
5. Aproveito para rascunho o outro lado do papel usado. & 4,27 & 0,93 \\
4. Coloco na caixa de coleta seletiva os papéis que podem ser reciclados. & 3,88 & 1,31 \\
6. Jogo copo descartável no coletor próprio para ele. & 3,75 & 1,39 \\
7. Mobilizo meus colegas para reduzir o consumo de energia. & 3,12 & 1,24 \\
1. (invertido) Jogo todo tipo de lixo em qualquer lixeira. & 2,92 & 1,20 \\
9. Converso com meus colegas sobre defesa do meio ambiente. & 2,77 & 1,15 \\
\hline Desejabilidade Social & 2,73 & 0,73 \\
\hline 3. Ao ver papel no chão, pego e jogo na lixeira. & 4,33 & 0,90
\end{tabular}


1. Se vejo alguém jogando lixo no coletor errado aviso que é para não fazer isso.

2. Saio recolhendo nas salas o material reciclável que as pessoas trazem de suas casas para a instituição.

O valor encontrado para o conjunto de itens de DS, conforme dados da referida amostra, ficou acima da média $(M=2,73 ; D P=073)$. Verificou-se a correlação de Pearson entre CE e DS, que mostrou-se alta e significativa $(r=0,42 ; p<0,01)$. Entretanto, vale salientar que a decisão de se continuar analisando a ECEAO se deve à diferença entre os valores apresentados pelos itens de DS, dos quais apenas um apresentou de fato um valor elevado. Portanto, considera-se que esse resultado não invalida os dados apresentados pelos itens de CE.

No que se refere à ECEAO, o valor do fator CE ficou acima da média $(M=3,74$; $D P=0,49)$, indicando que os trabalhadores adotam esse tipo de comportamento na Instituição pesquisada. Observa-se que alguns itens apresentaram média com valores acima de 4, especificamente os que se referem aos pontos reforçados pelo Programa de Sustentabilidade da Instituição. Os itens com valores mais baixos descrevem aspectos referentes justamente ao que o Programa ainda não incorporou como ação educativa.

Além das análises descritivas apresentadas foram ainda investigadas correlações entre as variáveis sociodemográficas e profissionais e o fator de $\mathrm{CE}$ da medida. Devido às características das variáveis envolvidas nas análises de correlação, foi utilizado o rho de Spearman para correlacionar CE com tempo de trabalho e se os participantes têm filhos. Os dados indicam que existe correlação positiva $(p<0,05)$ entre CE e tempo de trabalho na Instituição $(r=0,14)$, ou seja, quanto maior for o tempo em que o indivíduo trabalha nessa instituição, mais ele age de forma ecológica no ambiente de trabalho. Já a correlação entre CE e filhos é negativa $(r=-0,17, p<0,05)$, indicando que não é porque uma pessoa tem filho(s) que ela irá agir de forma ecológica no contexto organizacional. 
Para relacionar CE com variáveis categóricas e intervalares foi utilizada a correlação de Pearson. Foram encontradas correlações negativas $(p<0,05)$ entre CE e uso de copos na Instituição $(r=-0,20)$ e o item 11 de ativismo ambiental $(r=-0,20)$. Ou seja, quanto mais o indivíduo atua em conformidade com os princípios ecológicos em seu ambiente de trabalho, menos copos descartáveis ele utiliza e menos ativismo ele possui. Ou seja, o trabalhador dessa Instituição pode emitir comportamento ecológico no trabalho, mas não necessariamente ele apresenta um perfil ativista.

Foram ainda realizadas análises de regressão logística entre as variáveis sociodemográficas/profissionais e o fator de CE. Entraram no modelo como variáveis antecedentes: sexo, idade (pergunta aberta), vínculo institucional (cada tipo de vínculo foi transformado em uma dummy), tempo de trabalho na instituição e se ocupa cargo de chefia. Os resultados das análises são apresentados nas Tabelas 4 e 5.

\section{Tabela 4.}

Resumo do modelo de regressão padrão(b)

\begin{tabular}{c|c|c|c|c|c}
\hline Modelo & $\mathrm{R}$ & $\mathrm{R}^{2}$ & $\mathrm{R}^{2}$ Ajustado & $\begin{array}{c}\text { Erro padrão da } \\
\text { estimativa }\end{array}$ & Durbin-Watson \\
\hline 1 & $0,30(\mathrm{a})$ & 0,10 & 0,04 & 0,49 & 2,1 \\
\hline \hline
\end{tabular}

Nota: a. Preditores: (Constante), Cargo de chefia?, Terceirizados, Estagiário, Sexo, Tempo de trabalho na instituição, Idade, Servidor, Bolsista.

b. Variável dependente: Comportamento ecológico

A pressuposição de independência dos erros foi analisada por meio do teste DurbinWatson. Nesse teste, Field (2013) assume como critério que os valores devem estar próximos a dois para satisfazerem ao pressuposto de independência dos erros. Conforme pode ser observado na Tabela 4, o valor do teste de Durbin-Watson é igual a 2,1, portanto, a suposição de independência dos resíduos foi atendida.

Além disso, o índice de $R^{2}=0,10$ indica que as variáveis demográficas em questão explicam $10 \%$ do comportamento ecológico no trabalho. Considerando-se os estudos que 
envolvem a predição de comportamentos, esse pode ser considerado um índice razoável, uma vez que o modelo de regressão adotado reflete uma relação direta entre as variáveis antecedentes e a variável consequente.

Uma forma de identificar a multicolinearidade é examinar o fator de inflação da variância (VIF) que indica se um preditor tem um relacionamento linear forte com outro (valores acima de 10). Ainda se pode examinar o valor da tolerância que é o valor inverso de VIF (1/ VIF). Os valores de tolerância abaixo de 0,10 indicam multicolinearidade (Field, 2013). A Tabela 5 mostra as estatísticas de colinearidade.

Tabela 5.

Coeficientes do modelo de regressão

\begin{tabular}{|c|c|c|c|c|c|c|c|}
\hline \multirow[t]{2}{*}{ Modelo } & \multicolumn{2}{|c|}{$\begin{array}{c}\text { Coeficientes não } \\
\text { padronizados }\end{array}$} & \multirow{2}{*}{$\begin{array}{c}\begin{array}{c}\text { Coeficientes } \\
\text { padronizados }\end{array} \\
\beta \\
\end{array}$} & \multirow[t]{2}{*}{$\mathrm{t}$} & \multirow[t]{2}{*}{ Sig. } & \multicolumn{2}{|c|}{$\begin{array}{l}\text { Estatísticas de } \\
\text { colinearidade }\end{array}$} \\
\hline & $\mathrm{B}$ & $\begin{array}{c}\text { Erro } \\
\text { padrão }\end{array}$ & & & & Tolerância & VIF \\
\hline Constante & 3,85 & 0,40 & & 9,61 & 0,00 & & \\
\hline Terceirizado & $-0,02$ & 0,13 & $-0,02$ & $-0,13$ & 0,90 & 0,35 & 2,83 \\
\hline Estagiário & 0,04 & 0,37 & 0,01 & 0,09 & 0,93 & 0,86 & 1,17 \\
\hline Servidor & 0,07 & 0,18 & 0,04 & 0,39 & $-0,70$ & 0,52 & 1,93 \\
\hline Bolsista & $-0,10$ & 0,14 & $-0,09$ & $-0,71$ & 0,48 & 0,37 & 2,74 \\
\hline Sexo & $-0,16$ & 0,08 & $-0,16$ & 1,99 & 0,05 & 0,95 & 1,05 \\
\hline Idade & 0,01 & 0,01 & 0,15 & 1,73 & 0,09 & 0,79 & 1,27 \\
\hline Tempo de trabalho & 0,00 & 0,00 & 0,08 & 0,82 & 0,42 & 0,74 & 1,35 \\
\hline Cargo de chefia & $-0,09$ & 0,15 & $-0,05$ & $-0,60$ & 0,55 & 0,88 & 1,14 \\
\hline
\end{tabular}

Nota: Variável dependente: Comportamento ecológico

As estatística de colinearidade mostraram valores de VIF inferiores a 5 e valores de tolerância superiores a 0,10 , indicando, portanto, ausência de multicolinearidade e de singularidade (Field, 2013). Quanto aos resultados significativos da regressão, os dados evidenciam que das variáveis inseridas no modelo apenas sexo $(p<0,05)$ e idade $(p<0,1)$ predizem o $\mathrm{CE}$ no ambiente organizacional. Ou seja, as mulheres possuem mais comportamento ecológico do que os homens nessa instituição, e há uma tendência de que 
quanto mais velho o trabalhador for, mais ele se comporta de forma ecológica nesse contexto.

\section{Discussão e Considerações Finais}

Um dos objetivos específicos do presente estudo foi identificar quais são as ações de RSA adotadas pela Instituição pesquisada. Os relatórios de sustentabilidade destacam atividades relacionadas a quatro temas: economia de água, energia elétrica, papel e copo descartável na instituição. Esses temas possuem similaridade com os tipos de CE que a ECEAO mensura, o que é interessante para a identificação da relação entre o que o Programa institucional preconiza e a forma com que os trabalahdores se comportam.

Observando-se os resultados descritivos da escala, percebe-se que os itens que obtiveram maiores médias foram justamente aqueles relacionados aos temas trabalhados na instituição, em palestras, oficinas ou dinâmicas. Assim, os itens 2 (Apago a luz quando sou

o último a sair da sala), 3 (Evito desperdiçar água), 8 (Evito desperdiçar energia elétrica) e 5 (Aproveito para rascunho o outro lado do papel usado) foram os que alcançaram as maiores médias, aproximando-se do ponto mais alto da escala de medida, conforme pode ser observado na Tabela 3. Os itens com menor média foram referentes a descarte de lixo (item 1. Jogo todo tipo de lixo em qualquer lixeira) e um perfil mais ativista (item 9. Converso com meus colegas sobre defesa do meio ambiente). Lixo ainda não foi um tema trabalho pelo Programa de Sustentabilidade desta instituição e talvez exatament epor isso se apresente em menor grau no comportamento relatado pelos trabalhadores. Ativismo ambiental também não foi foco das ações de RSA.

Tais achados remetem ao terceiro objetivo específico do estudo e demonstram a relação direta entre os CEs mais característicos dos trabalhadores e as ações de RSA implementadas pelo Programa de Sustentabildiade da Instituição em questão. Isso 
demonstra a alta correspondência entre esses fatores. Além disso, considerando-se este resultado, faz sentido não terem sido encontradas evidências de validade discriminante da ECEAO considerando sua correlação com a variável ativismo ambiental - pelo menos na amostra desta pesquisa. Isto porque o ativismo não parece ser um comportamento incentivado nesse contexto, portanto pode não ter sido um fenômeno capturado adequadamente nesta pesquisa.

O objetivo geral deste estudo foi investigar o efeito preditor de variáveis sociodemográficas e profissionais sobre o CE no contexto organizacional. Os resultados demonstraram uma relação explicativa direta de $10 \%$ entre as variáveis em questão. Embora pareça ser baixo o efeito, o fato de ter sido encontrada uma relação direta entre características pessoais e comportamento ambiental já é de grande relevância para a área. Além do sexo, foi encontrada uma tendência de efeito da idade, corroborando os achados de Touguinha e Pato (2011). Tais resultados indicam que mulheres demonstram ter mais comportamentos ecológicos no trabalho do que os homens, e que quanto mais avançada for a idade do indivíduo, mais ele tende a se comportar de forma ecológica nesse mesmo contexto.

Considerando-se que se trata de uma pesquisa realizada em uma única organização, e neste caso de natureza pública, os resultados não podem ser generalizados. Nesse sentido, sugere-se a realização de mais estudos, envolvendo outras organizações para que se possa obter evidências mais concretas sobre a relação entre as variáveis sociodemográficas e o CE nesse contexto. 


\section{Considerações Finais sobre a Tese}

Sustentabilidade, responsabilidade socioambiental e comportamento ecológico foram os temas centrais tratados nesta tese. Os estudos realizados adotaram a sustentabilidade como embasamento para os temas abordados por cada um deles. Considerando-se que este trabalho foi estruturado em formato de manuscritos, faz-se necessário retomá-los separadamente. O primeiro estudo, exploratório, descritivo e de caráter mais qualitativo, buscou conhecer a concepção que os trabalhadores da Instituição pesquisada possuem sobre sustentabilidade. $\mathrm{O}$ conhecimento desse dado permite à própria Instituição identificar o que o seu Programa de Sustentabilidade precisa abordar nas ações de RSA implementadas nesse contexto.

Não é surpresa um resultado que demonstre o distanciamento do discurso de gestores e não gestores, mas é preciso utilizar esse dado de forma estratégica justamente para se reconhecer as lacunas existentes no Programa institucional. As dificuldades e limitações da implementação do Programa também perpassam por questões administrativas, da mais alta gestão da Instituição. Observa-se que, além de conhecer as representações das pessoas sobre sustentabilidade é preciso se fazer um diagnóstico cultural dessa instituição, uma vez que a cultura organizacional possui grande influência sobre políticas e diretrizes adotadas nesse contexto. Nesse sentido, é preciso identificar se a cultura dominante é voltada para a sustentabilidade, além de ser imprescindível relacionar essa busca pela sustentabilidade com as metas institucionais gerais - até para que seja possível traçar metas de RSA possíveis de serem alcançadas na realidade em questão.

O segundo manuscrito apresenta dois estudos sobre comportamento ecológico no contexto organizacional. O primeiro demonstrou evidências de validade da ECEAO, o que é de grande importância metodológica para a área, considerando-se que a medida de fato captura o fenômeno em questão. O segundo buscou identificar um efeito direto entre 
características sociodemográficas e profissionais sobre CE, e os resultados identificaram o efeito preditor direto de sexo e idade sobre o CE no trabalho. Além disso, foi encontrada uma relação direta entre os CEs mais fortemente emitidos pelos participantes da pesquisa e os temas abordados em ações de RSA pelo Programa de Sustentabilidade da Insituição.

Entende-se que, por se tratar de um estudo de caso, os resultados encontrados nos estudos aqui descritos não podem ser generalizados. Além disso, algumas limitações foram encontradas, tal como a falta de oportunidade de realização de grupos focais com trabalhadores provenientes de diferentes setores organizacionais, o que também limita a generalização dos resultados do primeiro estudo a toda a Instituição. No entanto, considerando-se a representatividade alcançada no segundo e no terceiro estudos, entendese que os resultados refletem a organização como um todo, podendo ser considados característicos da população de trabalhadores da Insituição pesquisada.

Observa-se que os temas aqui tratados são atualmente de grande relevância para a gestão organizacional, tendo em vista a realidade imposta pelos últimos acontecimentos mundiais, que impactam diretamente no equilíbrio entre os elementos constitutivos da natureza - em uma perspectiva ecocêntrica. $\mathrm{O}$ envolvimento das organizações, sejam elas públicas ou privadas, na busca pelo equilíbrio ambiental é de suma importância, tendo em vista o seu alcance não só como influenciadoras de condutas dentro e fora de seus contextos de trabalho, mas também considerando os seus impactos e sua responsabilidade por minimizá-los ou compensá-los adequadamente. Mas, conforme destaca Silva (2011), a sustentabilidade é, a princípio, tarefa de vários agentes (governo, clientes, indivíduos, consumidores, funcionários, empresas, entre outros), mas quando incorporadas à realidade organizacional amplia a responsabilidade das organizações e as coloca como protagonistas. No entanto, essa postura acaba extrapolando as próprias funções do Estado, inclusive 
levando a cobranças externas equivocadas quanto ao papel das organizações e as iniciativas que estas devem empreender na busca pela sustentabildiade.

Diante disso e de outras discussões apresentadas sobre o discurso empresarial sobre responsabilidade social, Silva (2011) ainda levanta algumas questões referentes à forma de atuação das organizações e as consequências da postura adotada por elas. Parece pertinente ressaltar o que a autora destaca sobre o efeito do discurso alientante desses agentes, colocando os públicos em posição passiva diante das ações organizacionais empreendidas e desconsiderando a possibilidade de indivíduos e grupos assumirem um papel mais amplo na promoção da responsabilidade socioambiental.

As pesquisas apresentadas nesta tese possuem algumas limitações. Por se tratar essencialmente de um estudo de caso, os resultados alcançados não podem ser generalizados para outros contextos organizacionais. Nesse sentido, sugere-se a realização de estudos futuros envolvendo diferentes tipos de organizações, com diferentes delineamentos metodológicos, incluindo observação, pesquisa-ação ou até mesmo testes de associação implícita. Sugere-se, ainda, a ampliação da amostra nessa mesma instituição, a fim de se obter uma representatividade ainda maior dos trabalhadores desse local. Especificamente sobre o estudo 1, seria interessante diversificar mais os participantes, realizando-se grupos focais com trabalhadores de outros setores além do setor de infraestrutura da instituição.

Quanto às contribuições deste trabalho, é preciso salientar alguns aspectos específicos. A proposição de uma definição para responsabilidade socioambiental das organizações, bem como o estabelecimento de um diálogo entre as psicologias organizacional e ambiental em umaperspectiva ecológica são contribuições teóricas relevantes aos estudos de sustentabilidade envolvendo contextos organizacionais e merecem continuidade em seu desenvolvimento. Embora ainda necessite de 
aprimoramentos, a identificação de adequação e de validade da Escala de Comportamento Ecológico no Ambiente Organizacional (Touguinha, 2008) é uma contribuição metodológica significativa para as áreas de conhecimento envolvidas nos estudos de sustentabilidade. Além disso, a avaliação da relação de ações propostas por um Programa de Sustentabilidade e o seu reflexo no comportamento dos trabalhadores (comportamento ecológico) fornecem subsídios para se ajustar os objetivos do Programa com as diretrizes e práticas propostas para o alcance efetivo das metas de sustentabilidade da Instituição pesquisada.

Finalmente, é preciso salientar a relevância do tema aqui tratado na atualidade, considerando-se o cenário mundial. Portanto, sugere-se uma agenda de pesquisas envolvendo variáveis diversas, tais como compatibilidade entre valores individuais e organizacionais; identificação com o meio ambiente, crenças ambientais e comportamento ecológico; cultura organizacional e sustentabilidade; mapeamento de diferentes culturas organizacionais e sua relação com RSA; modelos preditivos de comportamento ecológico e RSA; comprometimento e endosso dos trabalhadores a iniciativas de RSA nas organizações. Estas são apenas algumas sugestões de estudos relacionando sustentabilidade e organizações de trabalho, o que não esgota as possibilidades de pesquisa sobre o tema. 


\section{Referências}

Aligleri, L., Aligleri, L.M. \& Kruglianskas, I. (2009). Gestão socioambiental: Responsabilidade e sustentabilidade do negócio. São Paulo: Atlas.

Andrade, A. C. \& Romeiro, A. M. (2009). Capital natural, serviços ecossistêmicos e sistema econômico: Rumo a uma "economia dos ecossistemas". Texto para discussão IE/UNICAMP, n.159. Disponível em http://www.eco.unicamp.br/docprod/downarq.php?id=1789\&tp=a. Acesso em 25/01/2016.

Bandura, A. (1994). Self-efficacy. In V. S. Ramachaudran (Ed.), Encyclopedia of human behavior (pp. 71-81). New York: Academic Press.

Bissing-Olson, M.J., Iyer, A., Fielding, K.S. \& Zacher, H. (2013). Relationships between daily affect and pro-environmental attitude. Journal of Organizational Behavior, 34, $156-175$.

Bolderdijk, J.W., Steg, L. \& Postmes, T. (2013). Fostering support for work floor energy conservation policies: Accounting for privacy concerns. Journal of Organizational Behavior, 34, 195-210.

Borja, O. R. P. (2010). Ética \& educação ambiental: Estudo da percepção ambiental da alta administração das agências de viagem do Estado de Sergipe - Subsídios para a responsabilidade socioambiental empresarial no Parque Nacional Serra de Itabaiana/SE (Dissertação de Mestrado não publicada), Núcleo de Pós-graduação em Desenvolvimento e Meio Ambiente, Universidade Federal de Sergipe.

Bush, S. E. \& Ribeiro, H. (2006). Responsabilidade socioambiental empresarial: revisão da literatura sobre conceitos. Revista de Gestão Integrada em Saúde do Trabalho e Meio Ambiente, 4(2), 1-25. 
Cabestré, S. A., Graziadei, T. M., Filho, P. P. (2008) Comunicação estratégica, sustentabilidade e responsabilidade socioambiental: Um estudo destacando os aspectos teórico-conceituais e práticos. Conexão - Comunicação e cultura, 7, 40-58.

Camargo, B. V. \& Justo, A. M. (2013). Iramuteq: Um software gratuito para análises de dados textuais. Temas em Psicologia, 21(2), 513-518.

Campos-de-Carvalho, M. I., Cavalcante, S. \& Nóbrega, L. M. A. (2011). Ambiente. Em S. Cavalcante \& G. A. Elali, Temas básicos em psicologia ambiental. Petrópolis, RJ: Vozes.

Corral-Verdugo, V. (2010). Psicología de la sustentabilidad: Un análisis de lo que nos hace pro ecológicos y pro sociales. México: Trillas.

Corral-Verdugo, V. \& Pinheiro, J. (2004). Aproximaciones al estúdio de la conducta sustentable. Medio Ambiente y Comportamiento Humano, 5, 1-16.

Dias, R. (2011). Gestão Ambiental: Responsabilidade social e sustentabilidade. São Paulo: Atlas.

Dunlap, R. E., Van Liere, K. D., Mertig, A. G. \& Jones, R. E. (2000). New trends in measuring environmental atitudes: Measuring endorsement of the New Ecological Paradigm: A revised NEP scale. Journal of Social Issues, 56, 425-442.

Field, A. (2013). Discovering statistics using IBM SPSS Statistics (4th ed.). Los Angeles: Sage.

Friedman, M. (1984). Capitalismo e liberdade. São Paulo: Abril Cultural.

Hair, J. F., Black, B., Babin, B., Anderson, R. E., \& Tatham, R. L. (2009). Análise multivariada de dados. 6 ed. Porto Alegre: Bookman.

Harzem, P. \& Miles, T. R. (1978). Conceptual issues in operant behavior. New York: Willey 
Henderson, D. (2001). Misguided virtue: False notions of social corporate sustainability. London: Institute of Economic Affairs. Disponível em www.iea.org.uk/upldbook126pdf?pdf. Acesso em 27/09/2016.

Houaiss, A. \& Villar, M. S. (2009). Minidicionário Houaiss da língua portuguesa. Rio de Janeiro: Objetiva.

IUCN, UNEP, WWF (1991). Caring for the earth: A strategy for sustainable living. Gland, Switzerland: WWF International.

Kuhnen, A. (2011). Desenvolvimento sustentável. Em S. Cavalcante \& G. A. Elali, Temas básicos em psicologia ambiental. Petrópolis, RJ: Vozes.

Linnenluecke, M. K. \& Griffiths, A. (2010). Corporate sustainability and organizational culture. Journal of World Business, 45, 357-366.

Machado Filho, C. P. (2006). Responsabilidade social e governança: O debate das implicações. São Paulo: Pioneira Thomson Learning.

Miles, J. \& Shevlin, M. (2001). Applying regression \& correlation: A guide for students and researchers. London: Sage Publications.

Ministério do Meio Ambiente (MMA) (2009). A3P: Agenda ambiental na administração pública. Disponível em www.mma.gov.br/a3p. Acesso em 04/03/2016.

Neiva, E. R. \& Paz, M. G. T. (2007). Percepção de mudança organizacional: Um estudo em uma organização pública brasileira. $R A C, 11(1), 31-52$.

Nizeyimana, E. (2011). Fostering corporate social responsibility in Sub-Saharan Africa. Sub-Saharan Consulting Group, Oxford: United Kingdom. Disponível em http://www.slideshare.net/SUBSAHARAN/fostering-corporate-social-responsibility-insub-saharan-africa. Acesso em 15/02/2013.

Ones, D. S. \& Dilchert, S. (2012). Environmental sustainability at work: A call to action. Industrial and Organizational Psychology, 5, 444-466. 
Pasquali, L (Org.) (2005). Análise fatorial para pesquisadores, 163-184. Brasília: LabPAM.

Pato, C. M. L. (2004). Comportamento ecológico: Relação com valores pessoais e crenças ambientais (Tese de Doutorado não publicada), Programa de Pós-graduação em Psicologia Social, do Trabalho e das Organizações, Universidade de Brasília.

Pato, C. M. L. \& Campos, C. B. (2011). Comportamento ecológico. Em S. Cavalcante \& G. A. Elali, Temas básicos em psicologia ambiental. Petrópolis, RJ: Vozes.

Pato, C. M. L. \& Tamayo, A. (2006). A escala de comportamento ecológico: Desenvolvimento e validação de um instrumento de medida. Estudos de Psicologia (Natal), 11, 289-296.

Pinheiro, J. M. (2003). Cidadania corporativa: Um modelo de gestão socioambiental. Conjuntura \& Planejamento, 115, 29-34.

Pol, E. (2003). A gestão ambiental: Novo desafio para a psicologia do desenvolvimento sustentável. Estudos de Psicologia (Natal), 8(2), 235-243.

Rahman, N. \& Post, C. (2012). Measurement issues in environmental corporate social responsibility (ECSR): Toward a transparent, reliable, and construct valid instrument. Journal of Business Ethics, 105, 307-319.

Ribeiro, P. E. C. D. \& Ferreira, T. V. A. (2013). Sustentabilidade ambiental, clima ético e qualidade de vida no trabalho. Manuscrito não publicado, Instituto de Psicologia, Universidade de Brasília, Brasília, Brasil.

Ribeiro, P. E. C. D., Ferreira, T. V. A., Almeida J. G., Puente-Palacios, K. E., \& Barbosa, V. M. (2014). Esquemas mentais sobre responsabilidade socioambiental: Um estudo com gestores empresariais [Resumo]. Em Anais do VI Congresso Brasileiro de Psicologia Organizacional e do Trabalho. 
Ribeiro, P. E. C. D., Puente-Palacios, K. E. \& Ferreira, T.V. A. (2015). Responsabilidade socioambiental nas organizações: Uma medida de práticas organizacionais e endosso dos trabalhadores. Revista de Gestão Social e Ambiental, 9(1), 36-50.

Robertson, J. L. \& Barling, J. (2013). Greening organizations through leaders' influence on employees' pro-environmental behaviors. Journal of Organizational Behavior, 34, 176194.

Ruepert, A. M., Steg, L. \& Keizer, K. (2015). Theoretical basis for organizational proenvironmental research, in J. Barling, J. Robertson (Eds.), The psychology of green organizations. Oxford University Press: New York, pp. 33-57.

Ryle, G. (1949). The concept of mind. Londres: Hutchinson \& CO. Ltd.

Schultz, P. W. \& Zelezny, L. (1999). Values as predictors of environmental atitudes: Evidence for consistency across 14 countries. Journal of Environmental Psychology, 19, $255-265$.

Schwartz, S. H. (1999), A theory of cultural values and some implications for work. Applied Psychology: An International Review, 48(1), 23-47.

Silva, L. M. A. (2011). Várias faces de uma mesma moeda? As representações da responsabilidade social em um banco brasileiro (Tese de Doutorado não publicada), Programa de Pós-graduação em Psicologia Social, do Trabalho e das Organizações, Universidade de Brasília.

Stern, P. C. (2000). Toward a coherent theory of environmentally significant behavior. Journal of Social Issues, 56, 407-424.

Stern, P. C. \& Dietz, T. (1994). The value basis of environmental concern. Journal of Social Issues, 56, 121-145.

Stern, P. C., Dietz, T., Abel, T., Guagnano, G. A. \& Kalof, L. (1999). A value-belief-norm theory of support for social movementsn. Human Ecology Review, 6, 81-97. 
Strumpf, R. (2013). O capital natural. Disponível em http://www3.ethos.org.br/cedoc/ocapital-natural/\#.VsqBwijUPZV. Acesso em 10/02/2016.

Tabachnick, B., \& Fidell, L. (2007) Using multivariate statistics. (5a ed.). Allyn and Bacon.

Tachizawa, T. (2011). Gestão ambiental e responsabilidade social corporativa: Estratégias de negócios focadas na realidade brasileira. São Paulo: Atlas S.A.

Tamayo, A. (1996). Valores organizacionais. Em A. Tamayo, J. E. Borges-Andrade \& W. Codo (Orgs.), Trabalho, organizações e cultura (pp. 175-193). São Paulo: Cooperativa de Autores Associados.

Touguinha, S. (2008). Valores pessoais, crenças ambientais e comportamento ecológico em órgão público (Dissertação de Mestrado não publicada), Programa de Pós-graduação em Psicologia Social, do Trabalho e das Organizações, Universidade de Brasília.

Touguinha, S. \& Pato, C. M. L. (2011). Valores personales, creencias ambientales ecocéntrica y comportamiento ecológico de trabajadores brasileños: El caso del Ministerio Público del Distrito Federal y Territorios. Quaderns de Psicología, 13(1), $35-45$

Wackernagel, M., Schulz, N. B., Deumling, D., Linares, A. C., Jenkins, M., Kapos, V., . . Randers, J. (2002). Tracking the ecological overshoot of the human economy. Proceedings of the National Academy of Sciences, 99, 9266-9271.

WCED (1987). Our common future. Oxford and New York: Oxford University Press.

Wittgenstein, L. (1953/1987). Investigações filosóficas. Lisboa: Fundação Calouste Gulbenkian.

Young, R. (2004). Dilemmas and advances in corporate social responsibility in Brazil: The work of Ethos institute. Natural Resources Forum, 28, 291-301. 


\section{APÊNDICES}

A. Termo de Consentimento Livre e Esclarecido - TCLE

B. Instrumento de pesquisa 


\section{Termo de Consentimento Livre e Esclarecido}

Você está sendo convidado(a) a participar de uma pesquisa que tem como objetivo identificar a relação entre diretrizes organizacionais de responsabilidade socioambiental e comportamentos ecológicos no trabalho. A sua participação nesse estudo será no sentido de responder um questionário/participar de um grupo de discussão sobre o tema da pesquisa

Esclarecemos que a sua privacidade será respeitada, ou seja, seu nome ou qualquer outro dado ou elemento que possa, de qualquer forma, identificar você, será mantido em sigilo. Você também pode se recusar a participar do estudo, ou retirar o seu consentimento a qualquer momento, sem precisar justificar.

A pesquisadora responsável pela referida pesquisa é Patrícia Emanuele da Cruz Dias Ribeiro, aluna de doutorado do Instituto de Psicologia da Universidade de Brasília UnB, e se encontra disponível para esclarecer quaisquer dúvidas e outras informações adicionais por meio do e-mail: pecd.ribeiro@gmail.com e do telefone (61) 99655-5599.

Tendo sido orientado(a) quanto ao teor da pesquisa e compreendido a natureza e o objetivo do referido estudo, você manifesta seu livre consentimento em participar, estando ciente de que a pesquisa é de risco mínimo, ou seja, os mesmo presentes no cotidiano, e que sua participação não envolve qualquer valor econômico, a receber ou a pagar. Qualquer dúvida relativa a questões éticas o Comitê de Ética em Pesquisa que apreciou o projeto pode ser contatado no seguinte endereço: Avenida L3 Norte, s/n, Campus Universitário Darcy Ribeiro, Gleba A CEP: 70910-900 - Brasília - DF, ou ainda pelos telefones: (61) 3329-4607 / 3329-4638 ou pelo e-mail: cepbrasilia@fiocruz.br.

Brasília, Agosto de 2016.

Nome e assinatura do participante:

Patrícia Emanuele da Cruz Dias Ribeiro

Responsável pela pesquisa

Universidade de Brasília

Orientadora de doutorado: Prof. Dra. Ana Lúcia Galinkin 
Apêndice B

Instrumento de Pesquisa

\section{Pesquisa Acadêmica}

Responsabilidade Socioambiental

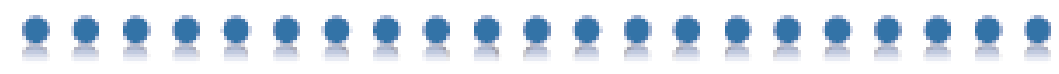

Você está sendo convidado(a) a dedicar alguns minutos do seu tempo para participar desta pesquisa sobre responsabilidade socioambiental das organizações. Este estudo faz parte de uma tese de doutorado da Universidade de Brasília, desenvolvida por Patrícia Emanuele Ribeiro (pecd.ribeiro@gmail.com), pesquisadora e psicóloga organizacional.

Sua participação é voluntária e sem qualquer remuneração ou beneficio. Você poderá se recusar a participar ou interromper sua participaçäo a qualquer momento. Isso não irá resultar em qualquer penalidade. Mas a sua contribuição será de grande importância para o desenvolvimento do trabalho, que poderá servir futuramente de base para a proposição de diretrizes de gestäo de responsabilidade socioambiental nas organizações.

Concordando em participar, você receberá todos os esclarecimentos necessários antes, durante $e$ após a finalização da pesquisa. Näo é necessário escrever o seu nome aqui, e nenhuma informaçäo que possa identificá-lo(a) será divulgada. Todas as informações fornecidas por você serão protegidas pelo mais rigoroso sigilo e serão analisadas em conjunto com as informações fornecidas por todos os participantes da pesquisa.

Este questionário é composto por 2 partes. Por favor, leia com atenção as instruçöes antes de respondê-lo e responda a todas as perguntas. Näo há respostas certas ou erradas. O que importa aqui é a sua opinião sincera.

Muito obrigada pela sua colaboraçäo! 
A seguir, descrevernos ações que você pode fazer no dia-a-dia do seu trabalho. Leia as afirmações e informe, marcando um $\mathbf{X}$, a frequência com que elas ocorrem, de acordo com a escala abaixo:

\begin{tabular}{ccccc}
\hline 1 & 2 & 3 & 4 & 5 \\
Nunca & $\begin{array}{c}\text { Quase } \\
\text { nunca }\end{array}$ & $\begin{array}{c}\text { Algumas } \\
\text { vezes }\end{array}$ & $\begin{array}{c}\text { Muitas } \\
\text { vezes }\end{array}$ & Sempre \\
& & &
\end{tabular}

QUANDO ESTOU NO TRABALHO:

1. Jogo todo fipo de lixo em qualquer lixeira.

2. Apago a luz quando sou o último a sair da sala.

$\begin{array}{lllll}1 & 2 & 3 & 4 & 5\end{array}$

3. Evito desperdiçar água.

$\begin{array}{lllll}1 & 2 & 3 & 4 & 5\end{array}$

4. Se vejo alguém jogando lixo no coletor errado aviso que é para năo fazer isso.

5. Saio recolhendo nas salas o material reciclável que as pessoas trazem de suas casas para a instituiçäo.

6. Se vejo que uma pessoa saiu da sala para ir embora deixando o computador ligado, desligo o equipamento.

7. Coloco na caixa de coleta seletiva os papéis que podem ser reciclados.

8. Aproveito para rascunho o outro lado do papel usado. \begin{tabular}{ll|l|l|l|l|l|}
1 & 2 & 3 & 4 & 5
\end{tabular}

9. Jogo copo descartável no coletor próprio para ele. $\quad \begin{array}{lllllll}1 & 2 & 3 & 4 & 5\end{array}$

10. Mobilizo meus colegas para reduzir o consumo de
energia.

11. Ao ver papel no chão, pego e jogo na lixeira. $\quad$\begin{tabular}{llllll}
\hline & 2 & 3 & 4 & 5
\end{tabular}

$\begin{array}{lllllll}\text { 12. Evito desperdiçar energia elétrica. } & 1 & 2 & 3 & 4 & 5\end{array}$

13. Não me preocupo com o desperdicio de papel. $\quad \begin{array}{llllll}2 & 3 & 4 & 5\end{array}$

14. Só me sirvo da quantidade de água que vou beber. $\quad \begin{array}{lllllll}1 & 2 & 3 & 4 & 5\end{array}$

15. Converso com meus colegas sobre defesa do meio ambiente. 
Preencha os campos abaixo sobre informações sociodemográficas e profissionais a seu respeito. Nenhuma informação pessoal será divulgada.

1. Sexo: $\square$ Feminino $\square$ Masculino

2. Idade: anos

3. Escolaridade:

$\square$ Ensino Médio incompleto $\square$ Ensino Médio completo $\square$ Graduação incompleta 口 Especialização incompleta $\square$ Mestrado incompleto - Graduação completa ¿ Especializaçäo completa ๑ Outra: $\square$ Mestrado completo

4. Estado civil:

5. Você tem filho(s)? \Sim $\square$ Não

6. Vínculo institucional: $\square$ Estagiário(a)

$$
\begin{gathered}
\square \text { Servidor(a) } \\
\square \text { Terceirizado(a) } \\
\square \text { Bolsista } \\
\square \text { Outro: }
\end{gathered}
$$

7. Há quanto tempo você trabalha nessa instituição? anos $\mathrm{e}$ meses.

8. Você tem cargo de chefia? $\square$ Sim $\square$ Não

9. Em qual setorlárea vocè trabalha atualmente?

10. Quantos copos descartáveis vocè usa por dia no seu trabalho?

11. Você participou de alguma atividade para discutir ou refletir sobre questöes socioambientais nos últimos dois anos? $\square$ Sim $\square$ Näo

12. Já participou de alguma atividade que buscava proteger o meio ambiente, independentemente do seu contexto de trabalho? $\square$ Sim $\square$ Năo

\section{Obrigada pela sua participação!}

